\title{
Polycyclic aromatic hydrocarbons (PAHs) and oxy- and nitro-PAHs in ambient air of the Arctic town Longyearbyen, Svalbard
}

\author{
Tatiana Drotikova ${ }^{1,2}$, Aasim M. Ali ${ }^{3}$, Anne Karine Halse ${ }^{4}$, Helena C. Reinardy ${ }^{1,5}$, and Roland Kallenborn ${ }^{1,2}$ \\ ${ }^{1}$ Department of Arctic Technology, University Centre in Svalbard (UNIS), Longyearbyen, 9171, Norway \\ ${ }^{2}$ Faculty of Chemistry, Biotechnology and Food Sciences, Norwegian University of Life Sciences \\ (NMBU), Ås, 1432, Norway \\ ${ }^{3}$ Department of Contaminants and Biohazards, Institute of Marine Research (IMR), Bergen, 5817, Norway \\ ${ }^{4}$ Department of Environmental Chemistry, Norwegian Institute for Air Research (NILU), Kjeller, 2007, Norway \\ ${ }^{5}$ Scottish Association for Marine Science (SAMS), Oban, Argyll, PA37 1QA, United Kingdom
}

Correspondence: Tatiana Drotikova (tatiana.drotikova@unis.no)

Received: 16 February 2020 - Discussion started: 28 February 2020

Revised: 6 June 2020 - Accepted: 17 June 2020 - Published: 27 August 2020

\begin{abstract}
Polycyclic aromatic hydrocarbons (PAHs) are not declining in Arctic air despite reductions in their global emissions. In Svalbard, the Longyearbyen coal-fired power plant is considered to be one of the major local sources of PAHs. Power plant stack emissions and ambient air samples, collected simultaneously at $1 \mathrm{~km}$ (UNIS) and $6 \mathrm{~km}$ (Adventdalen) transect distance, were analysed (gaseous and particulate phases separately) for 22 nitro-PAHs, 8 oxy-PAHs, and 16 parent PAHs by gas chromatography in combination with single quadrupole electron capture negative ionization mass spectrometry (GC-ECNI-MS) and gas chromatography in combination with triple quadrupole electron ionization mass spectrometry (GC-EI-MS/MS). Results confirm low levels of PAH emissions ( $\sum 16$ PAHs $=1.5 \mu \mathrm{g} \mathrm{kg}^{-1} \mathrm{coal}$ ) from the power plant. Phenanthrene, 9,10-anthraquinone, 9fluorenone, fluorene, fluoranthene, and pyrene accounted for $85 \%$ of the plant emission (not including naphthalene). A dilution effect was observed for the transect ambient air samples: $1.26 \pm 0.16$ and $0.63 \pm 0.14 \mathrm{ng} \mathrm{m}^{-3}$ were the sum of all 47 PAH derivatives for UNIS and Adventdalen, respectively. The PAH profile was homogeneous for these recipient stations with phenanthrene and 9-fluorenone being most abundant. Multivariate statistical analysis confirmed coal combustion and vehicle and marine traffic as the predominant sources of PAHs. Secondary atmospheric formation of 9nitroanthracene and 2+3-nitrofluoranthene was evaluated and concluded. PAHs partitioning between gaseous and particulate phases showed a strong dependence on ambient tem-
\end{abstract}

peratures and humidity. The present study contributes important data which can be utilized to eliminate uncertainties in model predictions that aim to assess the extent and impacts of Arctic atmospheric contaminants.

\section{Introduction}

Traditionally, Arctic regions are considered to be pristine and remote from the majority of potential large-scale emission sources in industrialized mid-latitude countries (Armitage et al., 2011; Macdonal et al., 2000; Barrie et al., 1992). Atmospheric transport is the most efficient way for polycyclic aromatic hydrocarbons (PAHs), released in the lower latitudes, to reach the Arctic (Friedman et al., 2014). Longrange atmospheric transport (LRAT) to Arctic regions has strong seasonality with an increased tendency during winter and spring (Willis et al., 2018). This is driven by a different mean circulation direction across the Arctic in winter compared to summer, the extension and significantly increased permeability of the Arctic front in winter, and the absence of wet removal of particles during transport (Willis et al., 2018). These factors explain observed maximum near-surface pollutant concentrations during winter and minimum levels during summer (Klonecki, 2003). Fossil fuel sources dominate total aerosol organic carbon in Arctic winter air, with a predominance of alkanes, PAHs, and phthalates (Fu et al., 2009). During the past decades, the background monitoring of at- 
mospheric pollutants in Ny-Ålesund, Svalbard, and Alert, Canada, have been an important data repository for information on the occurrence and LRAT of anthropogenic contaminants including persistent organic pollutants and PAHs in the Arctic regions. The data demonstrate ubiquitous distribution of PAHs on a global scale, including the Arctic. Confirmed occurrence of a pollutant in a polar environment is an important criterion considered by the Stockholm, Basel, and Rotterdam conventions (Fiedler et al., 2019). The United Nations Economic Commission for Europe (UNECE) has incorporated PAHs in the Convention on Long-range Transboundary Air Pollution (UNECE, 1998). Atmospheric PAHs are regulated in the USA, Canada, UK, and Europe (US EPA, 2011; Ontario Ministry of the Environment and Climate Change, 2016; UK Air DEFRA, 2007; EU Directive 2004/107/EC, 2005). PAHs are also included in the list of target chemicals of the Convention for the Protection of the Marine Environment of the North-East Atlantic (OSPAR). PAH concentrations are not declining in the Arctic despite global emission reductions (Yu et al., 2019), and PAHs are listed as "chemicals of emerging concern in the Arctic" (Balmer and Muir, 2017).

PAHs are byproducts of different incomplete combustion processes, mainly fossil fuels and biomass burning (Ravindra et al., 2008a). Their toxic and carcinogenic effects on both human health and ecosystems are well documented (Kim et al., 2013; Reynaud and Deschaux, 2006; Macdonald et al., 2010). Under unique Arctic weather conditions, with extreme temperatures, wind, and light seasonality, atmospheric PAHs may behave differently compared to in temperate climatic conditions. Low temperatures favour the partitioning of semi-volatile PAHs from gas phase to particulate phase, which makes them more persistent in the Arctic environment (Lammel, 2015). Due to extended winter darkness in the Arctic, photodegradation of PAHs is limited for several months. The transition from dark polar winter to the light spring and summer brings a large increase in the amount of available solar radiation and oxidants in the Arctic troposphere (Willis et al., 2018). PAHs react with a number of atmospheric oxidants, most notably the hydroxyl radical, ozone, the nitrate radical, and nitrogen dioxide (Keyte et al., 2013). This leads to their transformation into more toxic oxygenated and nitrated PAH derivatives (oxy-PAHs and nitro-PAHs). Oxyand nitro-PAHs are also constituents of raw coal and can be emitted with PAHs following the same combustion processes (W. Huang et al., 2014). Oxy- and nitro-PAHs have high toxicity (Onduka et al., 2012); they can act as direct mutagens, carcinogens, and oxidative stressors in biota (Durant et al., 1996). The biological effects of nitro- and oxy-PAHs can be greater than those of the parent PAHs (WHO, 2003). In remote locations they are found at concentrations near detection limits and thus are mostly not included in monitoring programmes, and the level of nitro- and oxy-PAHs in the Arctic atmosphere is unknown (Balmer and Muir, 2017).
The Arctic is warming at a higher rate than the global average and visible changes happen rapidly here. Thus, it is a key area for modelling studies on climate effects on contaminants with a main focus on LRAT from lower latitudes. As a consequence, local Arctic sources are usually disregarded, and a lack of information on local emission sources is a source of uncertainty in model predictions that often deviate significantly from observations (Schmale et al., 2018). Local emission sources may be of high importance in winter, when strong temperature atmospheric inversions can be frequent in Arctic region (Bradley et al., 1992). These episodes inhibit the mass and heat fluxes from the surface to the atmosphere, and consequently the dilution of surface emissions (Janhall et al., 2006; Li et al., 2019). This trapping of emissions results in poor air quality and can be potentially harmful to local people. Climate change introduces additional sources of PAHs to the Arctic region. In the past decade, human activities such as resource exploration, research, tourism, fisheries, and maritime traffic have increased substantially due to warming and corresponding reduction of sea ice, opening up new shipping routes (Jörundsdóttir et al., 2014). Warming may also enhance the volatilization of low molecular-weight (LMW) PAHs from ground surfaces (Friedman et al., 2014) and melting sea ice (Yu et al., 2019). The reactivity of PAHs in the gas phase is significantly greater than when associated with particles (Keyte et al., 2013); therefore increasing air temperatures can be expected to lead to increased levels of toxic nitro- and oxy-PAHs.

The need for a comprehensive assessment of local contaminant sources in Svalbard was acknowledged and initiated in the international Arctic Monitoring and Assessment Programme (AMAP); with the major focus on persistent organic pollutants (Pedersen et al., 2011), there is a scarcity of data on local sources of PAHs in Svalbard. A back-trajectory analysis of 20 years of data for three representative PAHs (Phe, Pyr, and BaPyr; see Table 1 for full names) suggested that Svalbard is impacted by air masses coming from eastern Russia, northern Europe, and northwest Russia during winter (Yu et al., 2019). Overall, combined European and Russian emissions accounted for more than $80 \%$ of episodic highconcentration events in Svalbard in 2007 (Balmer and Muir, 2017; Friedman and Selin, 2012). However, observed concentrations of Phe and Pyr from the Zeppelin station, Svalbard, were higher than model simulations, indicating important contributions of local sources of PAHs to the Arctic atmosphere, too (Yu et al., 2019). This study focused on the main settlement in Svalbard, Longyearbyen, with a population of approximately 2400 inhabitants and a high level of (partially seasonal) human activities (transport, coal mining, industry, tourism, and research). The local coal-fired power plant (PP) was hypothesized to be the major local source of PAHs, and the overall objectives of this study were to (1) evaluate PAH emissions from the local power plant, (2) examine concentrations and profile changes with distance from the PP, (3) quantify concentrations of PAHs and nitro- 
Table 1. Concentrations of PAHs $(\mathrm{G}+\mathrm{P})$ and percentage in the particulate phase (\%PM) in Longyearbyen power plant, UNIS, and Adventdalen. Data are average, minimum, and maximum; $n=6$ for each location.*

\begin{tabular}{|c|c|c|c|c|c|c|c|c|c|c|}
\hline \multirow[b]{2}{*}{ Compound name } & \multirow[b]{2}{*}{$\begin{array}{l}\text { Abbreviated } \\
\text { name }\end{array}$} & \multicolumn{3}{|c|}{ Power plant } & \multicolumn{3}{|c|}{ UNIS } & \multicolumn{3}{|c|}{ Adventdalen } \\
\hline & & $\begin{array}{r}\text { Mean } \\
n g m^{-3}\end{array}$ & $\begin{array}{r}\text { Min-max } \\
n g m^{-3}\end{array}$ & $\begin{array}{l}\text { Mean } \\
\% \mathrm{PM}\end{array}$ & $\begin{array}{r}\text { Mean } \\
\operatorname{pg~m}^{-3}\end{array}$ & $\begin{array}{r}\text { Min-max } \\
\operatorname{pg~m}^{-3}\end{array}$ & $\begin{array}{l}\text { Mean } \\
\% \text { PM }\end{array}$ & $\begin{array}{r}\text { Mean } \\
\operatorname{pg~m}^{-3}\end{array}$ & 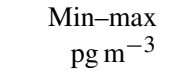 & $\begin{array}{l}\text { Mean } \\
\% \mathrm{PM}\end{array}$ \\
\hline Naphthalene & Nap & 51.82 & $32.74-59.82$ & 7.4 & $<\mathrm{MDL}$ & $<\mathrm{MDL}$ & - & $<$ MDL & $<$ MDL & - \\
\hline Acenaphthylene & Acy & 2.30 & $1.22-3.80$ & 0.6 & 16.89 & $7.14-29.15$ & 0.0 & 2.40 & $1.10-5.13$ & 0.0 \\
\hline Acenaphthene & Ace & 0.87 & $0.30-2.18$ & 8.4 & 48.48 & $24.29-72.99$ & 0.0 & 3.84 & $1.25-6.62$ & 0.0 \\
\hline Fluorene & Flu & 7.61 & $3.68-12.16$ & 4.6 & 170.50 & $136.5-236.0$ & 1.1 & 59.96 & $38.49-95.82$ & 1.8 \\
\hline Phenanthrene & Phe & 27.32 & $12.01-44.87$ & 5.6 & 409.20 & $368.5-470.0$ & 6.5 & 236.30 & $191.7-270.8$ & 3.7 \\
\hline Anthracene & Ant & 1.06 & $0.23-2.13$ & 0.0 & 18.04 & $12.29-25.52$ & 0.0 & 14.25 & $10.46-19.33$ & 3.5 \\
\hline Fluoranthene & Flt & 6.99 & $1.43-12.49$ & 3.9 & 28.45 & $24.14-36.06$ & 40.5 & 19.14 & $10.76-38.54$ & 23.2 \\
\hline Pyrene & Pyr & 4.40 & $1.08-7.35$ & 8.3 & 39.47 & $30.72-47.84$ & 26.8 & 27.17 & $20.91-35.89$ & 15.8 \\
\hline Benzo(a)anthracene & BaAnt & 0.13 & $0.04-0.20$ & 0.0 & 2.17 & $0.01-5.83$ & 68.2 & n.d. & n.d. & - \\
\hline Chrysene & Chry & 0.28 & $0.06-0.42$ & 0.0 & 7.32 & $2.60-13.47$ & 81.7 & 3.12 & $0.11-7.11$ & 64.1 \\
\hline Benzo $(b+k)$ fluoranthene & BbkFlt & n.d. & n.d. & - & 2.23 & $0.01-5.87$ & 100.0 & 0.75 & $0.01-2.79$ & 100.0 \\
\hline Benzo(a)pyrene & BaPyr & n.d. & n.d. & - & 0.89 & $0.01-2.46$ & 100.0 & 0.34 & $0.01-1.16$ & 100.0 \\
\hline Indeno(1,2,3-cd)pyrene & IPyr & n.d. & n.d. & - & 1.63 & $0.07-3.79$ & 100.0 & 0.71 & $0.07-2.67$ & 100.0 \\
\hline Dibenzo(a,h)anthracene & DBAnt & n.d. & n.d. & - & n.d. & n.d. & - & n.d. & n.d. & - \\
\hline Benzo(g,h,i)perylene & BPer & n.d. & n.d. & - & 3.92 & $1.44-8.12$ & 100.0 & 1.21 & $0.08-3.83$ & 100.0 \\
\hline$\sum 16 \mathrm{PAHs}$ & & 102.8 & $61.9-139.1$ & - & 749.2 & $687.4-866.9$ & -1 & 369.1 & $279.0-454.5$ & - \\
\hline 9-Fluorenone & 9-Flu & 12.35 & $5.57-19.54$ & 19.2 & 270.30 & $128.2-543.8$ & 41.7 & 139.40 & $110.2-177.2$ & 25.5 \\
\hline 9,10-Anthraquinone & 9,10-AntQ & 15.76 & $4.60-47.00$ & 21.3 & 163.50 & $105.2-269.1$ & 37.5 & 71.70 & $11.4-118.4$ & 43.9 \\
\hline $\begin{array}{l}\text { 4H-Cyclopenta(def) } \\
\text {-phenanthrene-4-one }\end{array}$ & cPPhe-4 & 1.30 & $0.51-2.55$ & 15.8 & 27.23 & $20.16-35.80$ & 65.5 & 18.77 & $11.97-39.10$ & 38.1 \\
\hline 9,10 -Phenanthrenequinone & 9,10-PheQ & 2.13 & $0.96-4.40$ & 0.0 & $<\mathrm{MDL}$ & $<\mathrm{MDL}$ & - & $<\mathrm{MDL}$ & $<\mathrm{MDL}$ & - \\
\hline Benzo(a)fluoren-11-one & BaFlu-11 & 0.16 & $0.08-0.23$ & 27.6 & 6.07 & $1.79-11.08$ & 100.0 & 2.23 & $0.71-4.36$ & 100.0 \\
\hline Benzanthrone & $\mathrm{BZT}$ & 0.87 & $0.14-1.31$ & 0.0 & 1.76 & $0.02-4.32$ & 96.7 & 0.10 & $0.02-0.58$ & 100.0 \\
\hline $\begin{array}{l}\text { Benzo(a)anthracene } \\
\text {-7,12-dione }\end{array}$ & BaAnt-7,12 & n.d. & n.d. & - & 2.20 & $0.01-4.86$ & 100.0 & 0.93 & $0.01-2.21$ & 100.0 \\
\hline 6H-Benzo(cd)pyren-6-one & BPyr-6 & n.d. & n.d. & - & n.d. & n.d. & - & n.d. & n.d. & - \\
\hline$\sum 8$ oxy-PAHs & & 32.6 & $15.8-73.1$ & - & 471.0 & $325.9-741.4$ & -1 & 233.1 & $124.7-337.1$ & - \\
\hline 1-Nitronaphthalene & 1-NNap & 2.19 & $0.99-4.69$ & 61.7 & 16.97 & $13.36-21.53$ & 0.1 & 5.02 & $1.91-9.84$ & 1.5 \\
\hline 2-Nitronaphthalene & 2-NNap & 0.26 & $0.11-0.40$ & 31.7 & 5.08 & $2.44-7.33$ & 3.1 & 1.88 & $1.29-2.83$ & 5.4 \\
\hline 2-Nitrobiphenyl & 2-NBip & 0.16 & $0.07-0.29$ & 39.9 & 0.99 & $0.82-1.20$ & 10.1 & 0.98 & $0.81-1.29$ & 5.9 \\
\hline 4-Nitrobiphenyl & 4-NBip & n.d. & n.d. & - & 2.23 & $1.51-2.68$ & 0.0 & 2.45 & $0.29-4.10$ & 0.0 \\
\hline 1,5-Dinitronaphthalene & 1,5-DNNap & n.d. & n.d. & - & 0.80 & $0.05-2.17$ & 80.0 & 0.93 & $0.05-3.72$ & 53.9 \\
\hline 5-Nitroacenaphthene & 5-NAce & n.d. & n.d. & - & 0.15 & $0.05-0.38$ & 0.0 & 0.30 & $0.05-1.62$ & 0.0 \\
\hline 2-Nitrofluorene & 2-NFlu & 0.04 & $0.02-0.14$ & 0.0 & 0.21 & $0.07-0.78$ & 15.1 & 0.59 & $0.07-1.05$ & 4.2 \\
\hline 9-Nitroanthracene & 9-NAnt & 0.08 & $0.02-0.23$ & 0.0 & 0.62 & $0.19-0.91$ & n.d. & 2.26 & $0.12-4.70$ & 57.8 \\
\hline 9-Nitrophenanthrene & 9-NPhe & n.d. & n.d. & - & 0.20 & $0.09-0.37$ & n.d. & 0.44 & $0.09-1.17$ & 25.0 \\
\hline 3-Nitrophenanthrene & 3-NPhe & 0.76 & $0.0003-1.93$ & 96.1 & n.d. & n.d. & - & n.d. & n.d. & - \\
\hline 2-Nitroanthracene & 2-NAnt & 0.31 & $0.07-0.62$ & 0.0 & n.d. & n.d. & - & n.d. & n.d. & - \\
\hline $2+3$-Nitrofluoranthene & $2+3-\mathrm{NFlt}$ & 0.52 & $0.06-1.14$ & 0.0 & 9.50 & $7.32-11.37$ & 94.5 & 12.30 & $4.68-26.66$ & 79.8 \\
\hline 4-Nitropyrene & 4-NPyr & 0.11 & $0.03-0.17$ & 0.0 & n.d. & n.d. & - & n.d. & n.d. & - \\
\hline 1-Nitropyrene & 1-NPyr & n.d. & n.d. & - & n.d. & n.d. & - & n.d. & n.d. & - \\
\hline 2,7-Dinitrofluorene & 2,7-DNFlu & 0.06 & $0.001-0.14$ & 0.0 & n.d. & n.d. & - & n.d. & n.d. & - \\
\hline 7-Nitrobenzo(a)anthracene & 7-NBaAnt & 0.58 & $0.11-0.93$ & 0.0 & n.d. & n.d. & - & n.d. & n.d. & - \\
\hline 6-Nitrochrysene & 6-NChry & n.d. & n.d. & - & n.d. & n.d. & - & n.d. & n.d. & - \\
\hline 1,3-Dinitropyrene & 1,3-DNPyr & n.d. & n.d. & - & n.d. & n.d. & - & n.d. & n.d. & - \\
\hline 1,6-Dinitropyrene & 1,6-DNPyr & n.d. & n.d. & - & n.d. & n.d. & - & n.d. & n.d. & - \\
\hline 1,8-Dinitropyrene & 1,8 -DNPyr & n.d. & n.d. & - & n.d. & n.d. & - & n.d. & n.d. & - \\
\hline 6-Nitrobenzo(a)pyrene & 6-NBaPyr & n.d. & n.d. & - & n.d. & n.d. & - & n.d. & n.d. & - \\
\hline$\sum 22$ nitro-PAHs & & 4.5 & $2.0-7.8$ & - & 36.8 & $30.3-46.1$ & - & 27.2 & $13.5-44.4$ & - \\
\hline
\end{tabular}

* Full results are given in the Supplement (Tables S9-S11); <MDL: below method detection limit; n.d. - not detected. 
and oxy-PAHs, in both gaseous and particulate phases, and (4) determine other potential local sources of PAHs and nitroand oxy-PAHs.

\section{Material and methods}

\subsection{Sampling site}

Svalbard is an archipelago located between latitudes 77 and $81^{\circ} \mathrm{N}$ in the western Barents Sea. Longyearbyen, being the largest populated settlement, was chosen as the study area. The local PP was installed in Longyearbyen in the 1980s and provides the community with sufficient electricity (45000 MW) and central heating supply (70000 MW) throughout the year (Bøckman, 2019). The PP is fuelled by coal produced in a nearby mine at Breinosa (mine no. 7). This coal has a distinct quality (brown, high-volatility bituminous coal with vitrinite reflectance $R_{o}=0.78 \%$; Marshall et al., 2015) and is well suited for energy production. Coal consumption is about $25000-30000 \mathrm{t} \mathrm{yr}^{-1}$. The $\mathrm{PP}$ has two boilers (32 MW each). The coal burning temperature is about $1000^{\circ} \mathrm{C}$ (Bøckman, 2019). Since December 2015, the flue gas purification system consists of a selective noncatalytic reduction (SNCR) system, an electrostatic precipitator (ESP), and a wet flue gas desulfurization (WFGD) scrubber. After SNCR the $\mathrm{NO}_{x}$ content in the flue gas is reduced by $50 \%$ by spraying urea solution as a reduction agent into the boiler. Further, in the ESP step, dust is electrically charged and deflected toward the collection electrodes. In the WFGD scrubber, the flue gas is cooled and desulfurized by sea water. Low emissions are reported: dust $1.5 \pm 0.2, \mathrm{SO}_{2}$ $0.3 \pm 0.1, \mathrm{NO}_{x} 244 \pm 19$, and CO $63 \pm 5 \mathrm{mg} \mathrm{Nm}^{-3}$ (Lundgjerdingen, 2017), reflecting the high efficiency of the flue gas cleaning system.

For PP emission analysis, stack emission air samples were collected at source (PP) and two locations at transect distance: the roof of the University Centre in Svalbard (UNIS, urban location, $1 \mathrm{~km}$ from PP) and the former northern lights observatory in Adventdalen (Adventdalen, rural location, $6 \mathrm{~km}$ from PP, $7 \mathrm{~km}$ to the active coal mine no. 7; Fig. 1). Sampling at UNIS and Adventdalen was performed simultaneously.

\subsection{Sample collection}

\subsubsection{Power plant}

A total of six low-volume $\left(1.3-3.0 \mathrm{~m}^{3}\right)$ samples of the PP stack emission were collected (Table S1 in the Supplement) under normal operating conditions on 27 September (PP1-PP3) and 2 October (PP4-PP6) 2018. Sampling was performed downstream from the WFGD scrubber, after all flue gas cleaning steps. The sampling probe (inner $\varnothing=11 \mathrm{~mm}$ ) was situated to face the direction of the flue gas. A custom-made low-volume, battery-powered air sampler
(Digitel, Switzerland) was used to pump the flue gas through the sampling material placed in a stainless steel cartridge (16249, Sartorius Stedim Biotech GmbH, Germany). The particulate phase was collected on quartz fibre filter (QFF; pre-burnt at $450^{\circ} \mathrm{C}$ for $6 \mathrm{~h}$; $\varnothing=47 \mathrm{~mm}$; no binder; Pallflex, USA) and the gaseous phase on polyurethane foam (PUF; Soxhlet pre-cleaned in toluene for $24 \mathrm{~h}$ followed by $24 \mathrm{~h}$ acetone wash; $\varnothing=50 \mathrm{~mm} ; L=75 \mathrm{~mm}$; Klaus Ziemer GmbH, Germany). Although the pump was operated at the maximum speed $\left(35 \mathrm{~L} \mathrm{~min}^{-1}\right.$, which corresponds to $6.1 \mathrm{~m} \mathrm{~s}^{-1}$ probe intake flow speed), an isokinetic sampling regime was not achieved. The flue gas parameters (temperature $8.9 \pm 0.5^{\circ} \mathrm{C}$, moisture $28 \pm 2 \%$, flow speed $18.1 \pm 0.8 \mathrm{~m} \mathrm{~s}^{-1}$, and density $1.24 \pm 0.2 \mathrm{~kg} \mathrm{~m}^{-3}$ ) were measured during the sampling by an FKT3DP1A multi-meter equipped with an S-type pitot probe (FlowKinetics LLC, USA).

\subsubsection{UNIS and Adventdalen}

The prevailing wind direction in Longyearbyen and Adventdalen is from the southeast. In summer, when the soil surface in Adventdalen becomes warmer than the water surface in Adventfjørd, the wind direction can temporarily change to northwesterly (Dekhtyareva et al., 2016; Esau et al., 2012). To focus on PP emission and avoid the peak of marine traffic in the summer, simultaneous sampling at UNIS and Adventdalen was carried out from 28 August to 28 September 2018 (Table S1) on days with a predicted northwesterly wind direction (Fig. S1 in the Supplement), using high-volume air samplers (TISCH-1000-BLXZ, TISCH Environmental Inc., USA) equipped with a dual-chamber sampling module (particle filter, stainless screen and vapour filter, glass cartridge). About $370 \mathrm{~m}^{3}$ of ambient air was collected over $24 \mathrm{~h}$ per sample (Table S1). For each station, six high-volume air samples were collected for particulate (QFF; pre-burnt at $450{ }^{\circ} \mathrm{C}$ for $6 \mathrm{~h} ; \varnothing=103 \mathrm{~mm}$; no binder; Munktell/Ahlstrom, Finland) and gaseous (PUF; Soxhlet pre-cleaned in toluene for $24 \mathrm{~h}$ followed by $24 \mathrm{~h}$ acetone wash; $\varnothing=65 \mathrm{~mm} ; L=100 \mathrm{~mm}$; Klaus Ziemer GmbH, Germany) phases. Weather parameters including ambient temperature, relative humidity, UV radiation, wind direction, and precipitation were recorded (Table S2). All samples (PP, UNIS, and Adventdalen) were kept intact inside the sampling unit after collection. In order to reduce the risk of post-collection contamination, the unit was sealed in two plastic bags for transportation to the lab, where samples were removed from the unit, sealed with layers of aluminium foil, and stored airtight in two plastic bags. Samples were kept frozen at $-20^{\circ} \mathrm{C}$ until analysis. A total of 18 samples (18 QFFs and 18 PUFs) and 8 field blanks (4 for PP and 4 for UNIS and Adventdalen) were collected.

\subsection{Analytical procedure}

In total, 16 PAHs and 8 oxy- and 22 nitro-PAHs (Table S3) were quantified using gas chromatography in combination 


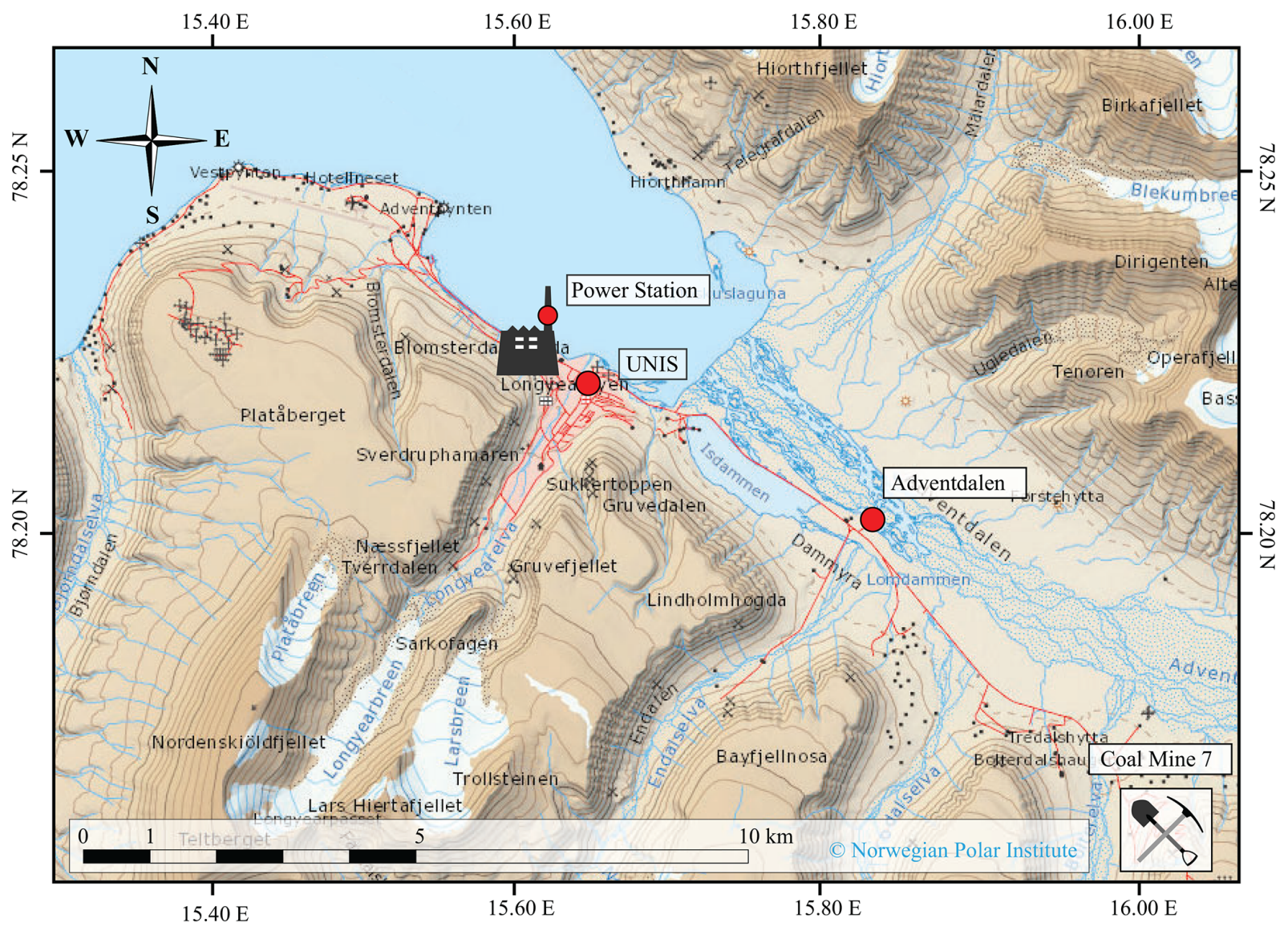

Figure 1. Air sampling transect locations in the vicinity of Longyearbyen.

with electron ionization triple quadrupole mass spectrometry (GC-EI-MS/MS) and gas chromatography in combination with electron capture negative ionization single quadrupole mass spectrometry (GC-ECNI-MS), respectively. Full details on analytical methods, including equipment and procedures, are outlined in the Supplement (Sect. S1, Tables S4 and S5). In brief, all QFF (particulate phase) and PUF (gaseous phase) samples were extracted separately by two different methods, followed by the same clean-up procedure. Several ${ }^{2} \mathrm{H}$-labelled PAH (dPAH) surrogates (16 dPAHs, 3 dOxy-PAHs, and 6 dNitro-PAHs) were added to samples prior to extraction. QFF samples were extracted with dichloromethane using a quick, easy, cheap, effective, rugged, and safe QuEChERS-like procedure developed previously for the analysis of particulate bound PAHs (Albinet et al., 2013, 2014). PUF samples were Soxhlet extracted with dichloromethane for $24 \mathrm{~h}$. The extracts were concentrated and cleaned up first with neutral alumina $\mathrm{Al}_{2} \mathrm{O}_{3}$ and then with neutral silica $\mathrm{SiO}_{2}$. Elutes were dried under gentle nitrogen stream and redissolved in approximately $100 \mu \mathrm{L} \mathrm{n}$ hexane. The purified samples were spiked with three labelled standards to evaluate the surrogate recoveries.

\subsection{Quality assurance}

Detailed information on method validation and quality control is provided in the Supplement (Sect. S2). Field ( $n=4$ for PP, $n=4$ for UNIS and Adventdalen combined) and laboratory ( $n=3$ for PP, $n=3$ for UNIS and Adventdalen combined) blanks were analysed in order to evaluate possible contamination during sample transport and analysis. The method detection limit (MDL) was determined based on blank values for each sampling material type (Table S6). High contamination of PUF blank samples by Nap and 9,10PheQ for UNIS and Adventdalen was found; these compounds were excluded from the final results. No blank correction was performed for the concentration calculations. Samples with PAH concentrations below the instrumental limit of quantification (LOQ) were replaced by $L O Q / 2$ for statistical analysis. The method efficiency was tested using QFF $(n=4)$ and PUF $(n=4)$ spiked samples (Table S7). Acceptable recoveries ranged between $63 \%-109 \%$ for dPAHs, $56 \%-68 \%$ for dOxy-PAHs, and $44 \%-89 \%$ for dNitroPAHs (Table S8). 


\subsection{Statistical analysis}

Statistical analyses of compound concentrations were performed with Minitab 18 Statistical Software (Minitab LLC, Pennsylvania, USA). Normality and homogeneity of variances were tested with Shapiro-Wilk and Levene's tests, respectively. A Mann-Whitney $U$ test was performed to test significant differences between sampling locations. Spearman's correlation was used to investigate relationships between different variables. The statistical significance was set at $p<0.05$, unless stated.

Principle component analysis (PCA) was performed for PAH source apportionment. A $6 \times 29$ matrix (sample number $\times 29$ detected compounds, including 14 PAHs and 15 nitro- and oxy-PAHs) dataset was used to assess the source contribution to PAHs for each location (UNIS and Adventdalen). Total PAH concentrations (gaseous and particulate, $\mathrm{G}+\mathrm{P}$ ) were used to minimize the influence of partitioning, ageing, and photochemical degradation (Kim et al., 2009). PCA was based on a correlation matrix to standardize scales and weight all variables equally (Holmes et al., 2017). PCA was first applied on the concentrations matrix only, and then additional parameters (weather and diagnostic ratios) were carefully included in order to explain the observed sample groupings.

\section{Results and discussion}

\subsection{Longyearbyen power plant PAH emission profile}

Individual concentrations and phase distribution (percentage of particulate matter, \%PM) of target PAHs are summarized in Table 1. The sum of total $(\mathrm{G}+\mathrm{P})$ concentration of the 16 priority PAHs ( $\sum 16$ PAHs; U.S. Environmental Protection Agency) in the purified flue gases emitted from the PP is $0.106 \mu \mathrm{g} \mathrm{m}^{-3}$, which corresponds to $1.5 \mu \mathrm{g} \mathrm{kg}^{-1}$ coal. Currently, there is no PAH emissions standard for coal-fired power plants in Norway. However, compared to the Canadian emission limits of PAHs for municipal solid waste incinerators of $5 \mu \mathrm{g} \mathrm{m}^{-3}$ ( $\mathrm{Li}$ et al., 2016), the Longyearbyen PP emissions are a factor of 3 lower. About $94 \%$ of 16 PAHs were emitted in a gas phase, in agreement with earlier studies (Li et al., 2016; Wang et al., 2015; Yang et al., 1998). The emission profile of the Longyearbyen PP is dominated by LMW PAHs (two and three rings), which represents $89 \%$ of $\sum 16$ PAHs emission; high molecular-weight (HMW) PAHs (5-7 rings) were not detected, likely due to their low vapour pressure and thus association with particles. A combination of ESP and WFGD has a removal efficiency of PM of up to $99.9 \%$ (Wang et al., 2019). Fine cooling of the PP flue gas $\left(8.9 \pm 0.5^{\circ} \mathrm{C}\right)$ by cold sea water facilitates high PM collection efficiency as well (Noda and Makino, 2010; Wang et al., 2019). As a result, PP dust emissions are below the ultra-low standard of $5 \mathrm{mg} \mathrm{m}^{-3}$ (Zhao et
Table 2. Ratios of individual oxy- and nitro-PAHs to their corresponding parent PAHs $(\mathrm{G}+\mathrm{P})$ in Longyearbyen power plant; averages of individual ratio values $(n=6)$ with standard deviation are presented.

\begin{tabular}{lr}
\hline Ratio & \multicolumn{1}{l}{ Mean \pm SD } \\
\hline Nitro-PAH / PAH & \\
\hline 2-NFlu / Flu & $0.004 \pm 0.005$ \\
3-NPhe / Phe & $0.028 \pm 0.028$ \\
2-NAnt / Ant & $0.15 \pm 0.11$ \\
9-NAnt / Ant & $0.04 \pm 0.03$ \\
2+3-NFlt / Flt & $0.03 \pm 0.02$ \\
7-NBaAnt / BaAnt & $5.37 \pm 3.87$ \\
\hline Oxy-PAH / PAH & \\
\hline 9,10-PheQ / Phe & $0.08 \pm 0.01$ \\
cPPhen-4 / Pyr & $0.31 \pm 0.11$ \\
BaFlu-11 / Chry & $0.65 \pm 0.34$ \\
9-Flu / Phe & $0.47 \pm 0.13$ \\
9-Flu / Flu & $1.67 \pm 0.29$ \\
9,10-AntQ / Ant & $12.17 \pm 7.31$ \\
\hline
\end{tabular}

al., 2017) at $1.5 \pm 0.2 \mathrm{mg} \mathrm{m}^{-3}$ (Lundgjerdingen, 2017). The PAH emissions profile was dominated by Nap and Phe, accounting for $53 \%$ and $27 \%$ of $\sum 16$ PAHs, followed by Flu, Flt, and Pyr. Nap and Phe are often reported as major emitted compounds from power plants equipped with analogous exhaust cleaning systems and/or burning the same type of coal (Hsu et al., 2016; Li et al., 2016; Wang et al., 2015). A similar PAH emissions profile was reported by Hsu et al. (2016) for the power plant in central Taiwan (Table S12). A higher flue gas dust concentration and different coal sources resulted in $40 \%$ emissions of four-ringed PAHs compared to $11 \%$ for Longyearbyen PP. Operation conditions and boiler type can have significant effects on emitted PAH profiles and concentrations (Wang et al., 2015) as can combustion temperature (Peng et al., 2016) and geological maturity (W. Huang et al., 2014).

Nitro- and oxy-PAHs are constituents of raw coal and can also be produced from parent PAH compounds during hightemperature coal combustion (W. Huang et al., 2014). The yields of individual nitro-PAHs from the PP were 1-2 orders of magnitude lower than those of their corresponding parent PAHs, and individual concentrations were at or below $1.7 \mathrm{ng} \mathrm{m}^{-3}$; 1-NNap was the most abundant nitro-PAH. W. Huang et al. (2014) investigated the same type of coal (bituminous, $R_{0}=0.77 \%$ ), burnt at lower temperatures in a honeycomb briquette stove; nitro-PAHs were absent in the raw coal and calculated nitro-PAH / PAH ratios were $>1$, confirming the formation of nitro-PAH compounds during coal combustion. In contrast, in the present work, the same daughter-to-parent PAH ratios were $<1$ (Table 2), indicating an absence of nitro-PAH formation during coal combustion or possible thermal degradation of nitro-PAH at $1000^{\circ} \mathrm{C}$. 
The yields of oxy-PAHs were orders of magnitude higher than nitro-PAHs because oxy-PAHs can be produced by reaction of $\mathrm{PAH}$ with $\mathrm{O}$ ' or ' $\mathrm{OH}$ radicals generated continuously by radical chain reactions during combustion (W. Huang et al., 2014). 9-Flu and 9,10-AntQ were the most abundant among the oxy-PAHs (12.4 and $15.6 \mathrm{ng} \mathrm{m}^{-3}$, respectively), and concentration of 9,10-PheQ was a factor of 6 lower. The calculated ratios of oxy-PAH to corresponding parent $\mathrm{PAH}$ were lowest for 9,10 -PheQ/Phe and highest for 9,10AntQ/Ant (Table 2). This can be due to a higher content of Phe in coal, as well as different reaction rates of Phe, Ant, and Flu with $\mathrm{O}^{\prime}$ or ${ }^{\prime} \mathrm{OH}$ radicals. Difference between the reaction rates of Flu and Ant can possibly be explained by different reaction pathways; Flu undergoes $\mathrm{H}$ atom abstraction at the 9-position to form 9-Flu, while Ant requires $\mathrm{OH}$ attack on the aromatic ring (Brubaker and Hites, 1998). Ant and Phe have essentially the same three-ring structure, only differing by the relative position of their aromatic rings. However, Ant appears to be significantly more reactive, due to the sterically unhindered molecular structure of Ant (Keyte et al., 2013). The formation of specific PAHs is also a temperaturedependent process (Peng et al., 2016).

Ant, BaAnt, and Chry are often used as indicators of coal combustions (Zheng et al., 2019; Wu et al., 2014; Wang et al., 2009); however, their concentrations in the flue gas of the Longyearbyen PP were negligible. This demonstrates the strong importance of determining indicatory $\mathrm{PAH}$ profiles for individual combustion sources for correct source identification. PAH emissions from different coal plants are hard to compare because they are affected by many factors including coal type, boiler load, combustion mode (Wang et al., 2015), and flue gas cleaning systems. Nap was the most abundant PAH emitted from the Longyearbyen PP. Due to its ubiquitous presence, Nap was not regarded as a suitable marker. Further, Phe, Flu, Flt, Pyr, 9-Flu, and 9,10-AntQ were the main PAHs and oxy-PAHs detected in the Longyearbyen PP flue gas (Fig. 2); therefore the presence and diagnostic ratios (Table 3 ) of these compounds were used as markers of the PP source in the present work. In Yu et al. (2019), coal combustion was identified as the main source (68\% contribution) of PAHs, at the Zeppelin monitoring station at $\mathrm{Ny}-$ Allesund, Svalbard, and Phe, Flu, Flt, and Pyr were the main contributors, most likely attributable to the Longyearbyen PP located $115 \mathrm{~km}$ southeast of $\mathrm{Ny}$-Ålesund. Overall, the total flue gas emissions were $960000 \mathrm{Nm}^{3} \mathrm{~d}^{-1}$ (Lundgjerdingen, 2017), and average daily emissions of $\Sigma 16$ PAHs, $\Sigma 8$ oxyPAHs, and $\Sigma 22$ nitro-PAHs are 98.7, 31.3, and $4.3 \mathrm{mg}$, respectively.

\subsection{UNIS and Adventdalen}

\subsubsection{Ambient concentrations and PAH profiles}

The concentrations of PAHs and oxy-PAHs measured at UNIS were a factor of 2 higher than at Adventdalen, while nitro-PAH levels differed less (Table 1). $\Sigma 15$ PAHs were $749.2 \pm 72.6$ (UNIS) and $369.1 \pm 66.7 \mathrm{pg} \mathrm{m}^{-3}$ (Adventdalen); $\Sigma 7$ Oxy-PAHs were $471.0 \pm 150.8$ (UNIS) and $233.1 \pm 68.3 \mathrm{pg} \mathrm{m}^{-3}$ (Adventdalen); $\Sigma 22$ nitro-PAHs were an order of magnitude lower than both parent PAHs and oxy-PAHs, with average values of $36.8 \pm 6.2$ (UNIS) and $27.2 \pm 11.1 \mathrm{pg} \mathrm{m}^{-3}$ (Adventdalen). The UNIS and Adventdalen chemical profiles of PAHs and oxy-PAHs were similar, while the profiles of nitro-PAHs differ (Fig. S2). Proportions of 1- and 2-NNap were higher in UNIS samples (about $60 \%$ of $\Sigma 22$ nitro-PAHs), while 9-NAnt and $2+3$-NFlt showed higher contributions into the nitro-PAH profile of samples from Adventdalen (about $55 \%$ of $\Sigma 22$ nitro-PAHs).

Among the parent PAHs, Phe (ranging from 191.7 to $470.0 \mathrm{pg} \mathrm{m}^{-3}$ ) and Flu (ranging from 38.5 to $236.0 \mathrm{pg} \mathrm{m}^{-3}$ ) were the most abundant in the present study. The Phe and Flu concentrations measured in Longyearbyen (UNIS and Adventdalen) were 2 orders of magnitude higher than those detected at the Zeppelin station and the same order of magnitude as in Birkenes (southern mainland Norway) for the same period (Table S13). The PAH profiles were dominated by Phe and Flu at all sites (Fig. S3). A higher proportion of Phe was observed in Longyearbyen samples. The measured PAH concentrations in the present study were in agreement with the 2-decade average data reported for the Arctic monitoring stations in Svalbard (Zeppelin) and Finland (Pallas) and were about an order of magnitude higher compared to the Canadian Arctic (Alert) concentrations (Yu et al., 2019). The PAH levels observed in Longyearbyen were significantly (up to 2 orders of magnitude) lower compared to rural sites in Europe and China (Table S14).

Among measured oxy-PAHs, concentrations of 9-Flu and 9,10-AntQ were the highest in the present study. The 9-Flu level $\left(270.3 \pm 146.9 \mathrm{pg} \mathrm{m}^{-3}\right.$ at UNIS and $139.4 \pm 24.9 \mathrm{pg} \mathrm{m}^{-3}$ in Adventdalen) was a factor of 3 higher than reported for Pallas and Råö (southern Sweden) background stations (Brorström-Lundén et al., 2010), while 9,10-AntQ (163.5 \pm $57.4 \mathrm{pg} \mathrm{m}^{-3}$ at UNIS and $71.7 \pm 39.2 \mathrm{pg} \mathrm{m}^{-3}$ in Adventdalen) in Longyearbyen was equal to the winter levels in central European background air (Lammel et al., 2020). The sum of oxy-PAHs detected at UNIS was similar to rural sites in eastern England (Alam et al., 2014) and the central Czech Republic (Lammel et al., 2020) but was significantly lower than in rural southern China (B. Huang et al., 2014) and the French Alps (Albinet et al., 2008).

1-NNap and 2+3-NFlt were the most abundant nitroPAHs detected at UNIS and Adventdalen. The level of 2+3NFlt $\left(9.5 \pm 1.6\right.$ at UNIS and $12.3 \pm 7.7 \mathrm{pg} \mathrm{m}^{-3}$ in Adventdalen) was an order of magnitude higher than that at Råö and Pallas stations (Brorström-Lundén et al., 2010), and 1NNap average concentrations were 17.0 \pm 3.0 at UNIS and $5.0 \pm 3.2 \mathrm{pg} \mathrm{m}^{-3}$ in Adventdalen. Overall, nitro-PAH concentrations were similar to those reported for the Pallas and Råö Scandinavian stations (Brorström-Lundén et al., 2010) and 
Table 3. Source identification based on diagnostic ratios derived from total $(G+P)$ concentrations; averages of individual ratio values $(n=6)$ with standard deviation are presented.

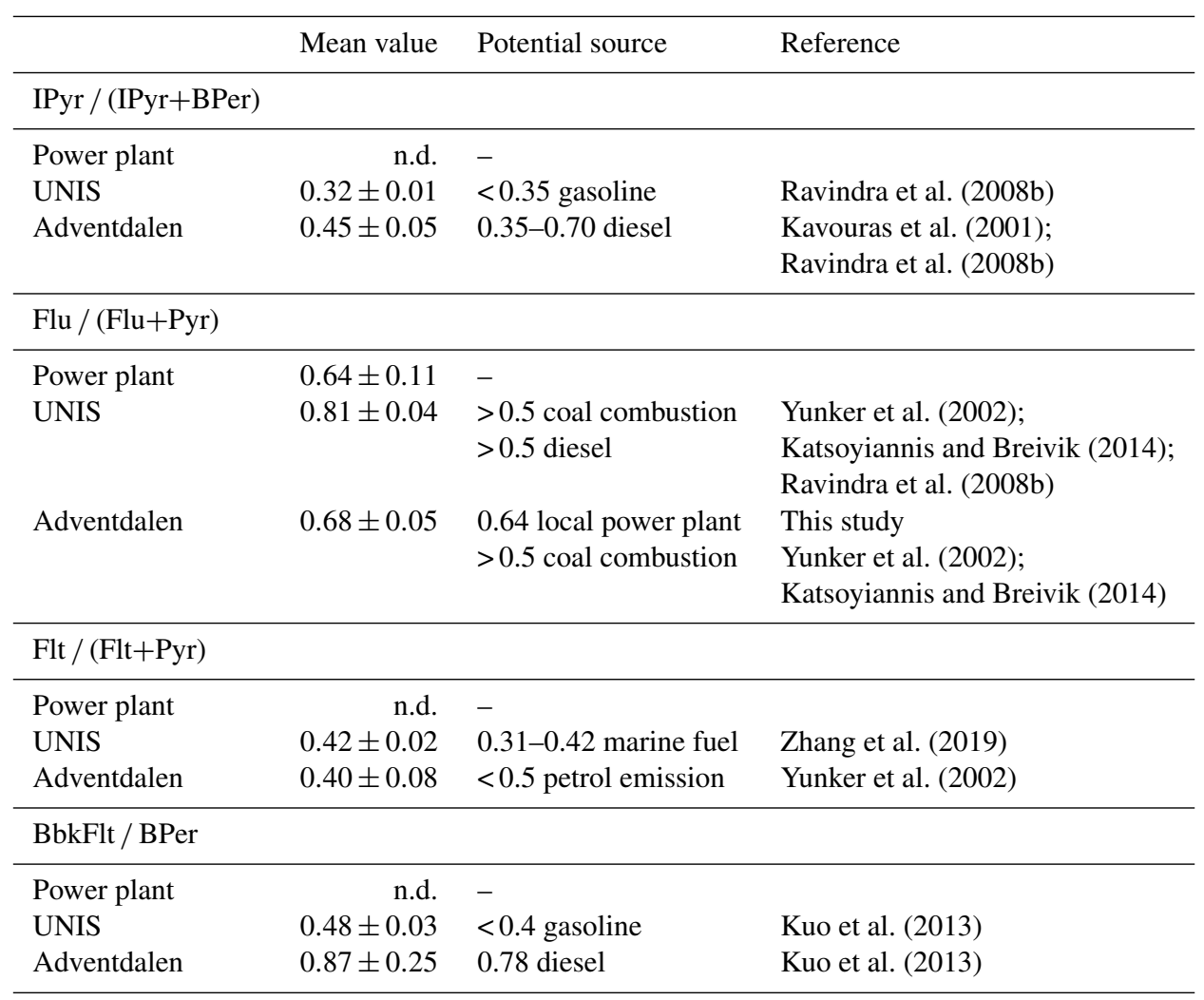

the rural site in the Czech Republic which is representative of central European background levels (Lammel et al., 2020).

\subsubsection{Gas-particle partitioning}

Gas-particle partitioning is an important process that controls transport, degradation, and distribution patterns of contaminants in and between environmental compartments (Finlayson-Pitts and Pitts, 1999; Lammel et al., 2009; Franklin et al., 2000). The sampling campaign in the present study was conducted from late Arctic summer until early autumn and during this period the air temperature varied from +6.8 in August to $-4.4{ }^{\circ} \mathrm{C}$ in September and several precipitation events (snow and rain) occurred. In general, LMW PAHs were found in the gas phase, while HMW PAHs were present in the particulate phase (Table 1), which is in accordance with their physico-chemical parameters, such as the octanol-air partition coefficient, vapour pressure, and molecular weight (Table S3; Tomaz et al., 2016; Shahpoury et al., 2016). Repartitioning between phases (Fig. 3) mainly impacted semi-volatile compounds with three and four aromatic rings (Flt, Pyr, BaAnt, Chry; 2-NFlu, 9-Flu, cPPhe-4, 9,10AntQ, 9-NAnt, and 2+3-NFlt) as a response to changing meteorological conditions (Hu et al., 2019). Strong negative correlations of the percentage of PAH determined in particulate phase (\%PM) with ambient temperature were confirmed for most of these compounds (Table S15). \%PM also depends on aerosol surface area, organic matter, and black carbon content (Lohmann and Lammel, 2004).

Compared to Adventdalen, the urban UNIS location ensures a higher level of PAHs emitted from different nearby anthropogenic sources, including the PP. Furthermore, low ambient temperature reinforces the partitioning of freshly emitted gaseous PAHs to the particulate phase. As a result, $\% \mathrm{PM}$ at UNIS was higher than in Adventdalen. Deposition (wet and dry) and chemical reactions with atmospheric oxidants are important removal processes of PAH from air (Keyte et al., 2013). On the local scale, within an hour of travel time from PP to Adventdalen, it is not expected that photolytically initiated transformation of the freshly emitted PAHs has a strong influence on gas phase concentrations and consequently on \%PM. Dry deposition rates vary depending on the type of adsorbing particle (mass, size, aerodynamic properties, shape, and chemical composition) and the atmospheric conditions (Weinbruch et al., 2018) and may be a dominant PAH removal process in source areas (Sharma and McBean, 2002).

The influence of wet deposition was indicated by a significant negative correlation between the amount of precipitation and concentrations of several particle-bound HMW 
(a) PAHs

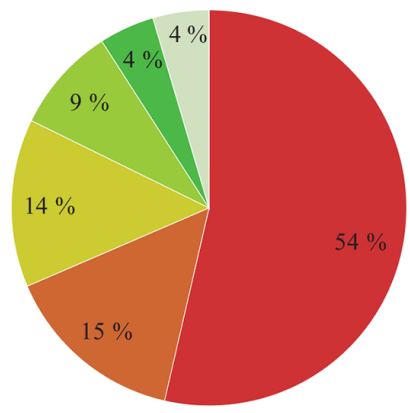

(c) Nitro-PAHs

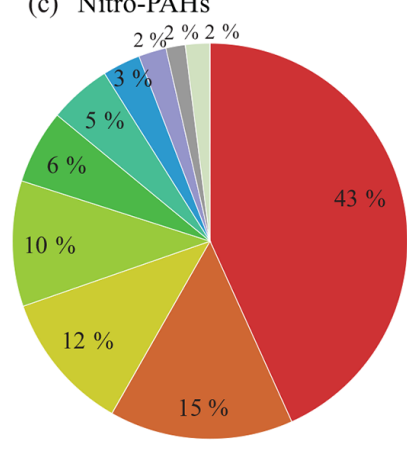

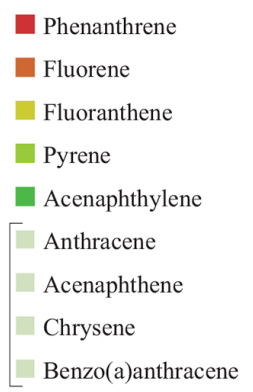

1-Nitronaphthalene

3-Nitrophenanthrene

7-Nitrobenzo(a)anthracene

2+3-Nitrofluoranthene

2-Nitroanthracene

2-Nitronaphthalene

2-Nitrobiphenyl

4-Nitropyrene

9-Nitroanthracene

2,7-Dinitrofluorene

2-Nitrofluorene (b) Oxy-PAHs

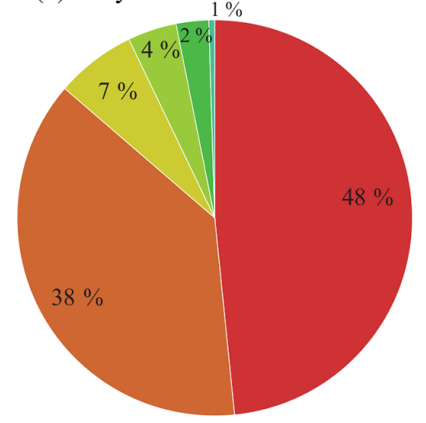

9,10-Anthraquinone

9-Fluorenone

9,10-Phenanthrenequinone

Cyclopenta(def)phenanthrene-4-one

Benzanthrone

Benzo(a)fluoren-11-one (d) PAHs, oxy- and nitro-PAHs

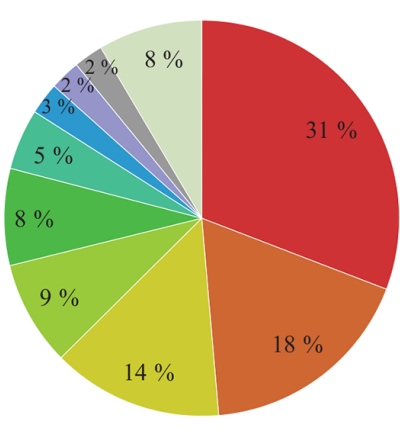

- Phenanthrene

a,10-Anthraquinone

9-Fluorenone

aluorene

n Fluoranthene

ayrene

acenaphthylene

a 1-Nitronaphthalene

घ9,10-Phenanthrenequinone

Other

Figure 2. Proportion of (a) PAHs, (b) oxy-PAHs, (c) nitro-PAHs, and (d) all the PAH derivatives (G+P; excluding Nap) in the Longyearbyen power plant emission $(n=6)$.

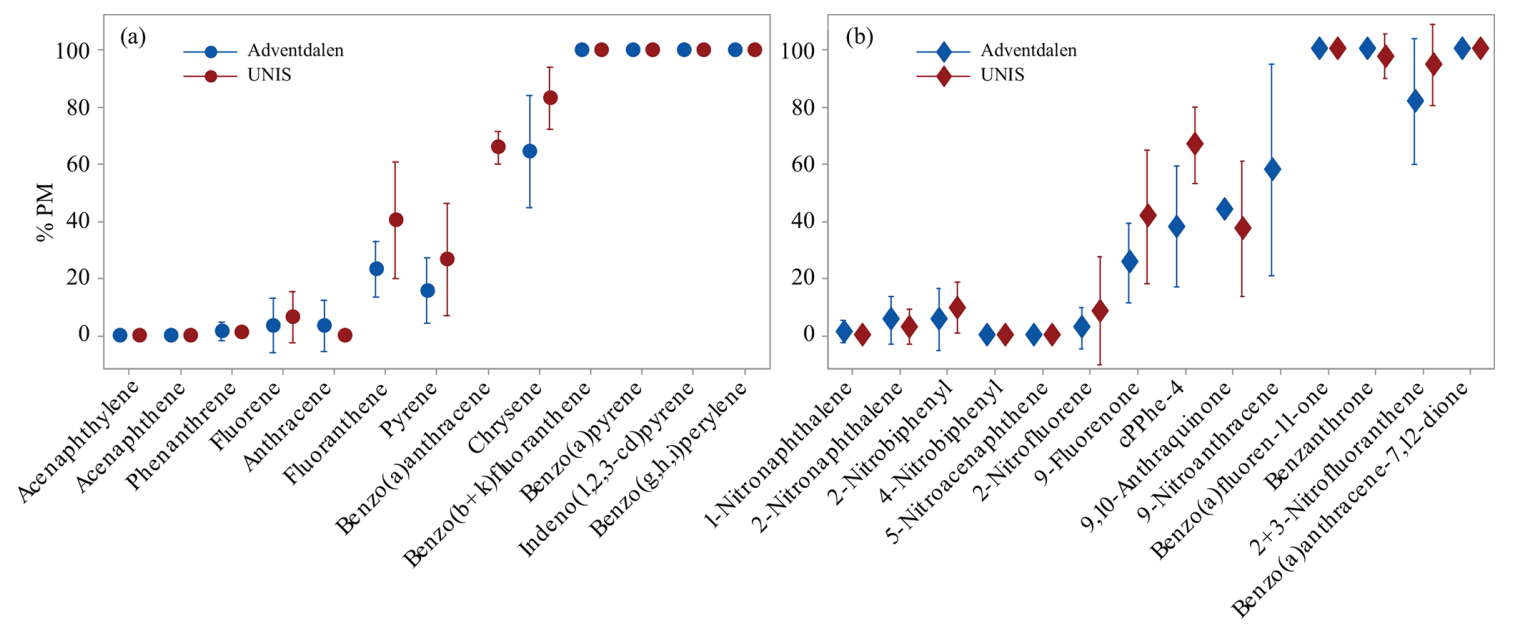

Figure 3. Percentage of (a) PAHs and (b) nitro- and oxy-PAHs determined in particulate phase (\% PM) at UNIS ( $n=6)$ and Adventdalen $(n=6)$; individual standard deviations are used to calculate the intervals.

PAHs (Chry, BbkFlt, IPyr, BPer, BaFlu-11, and BaAnt-7,12) as well as semi-volatile Phe, Flt, and Pyr, which are more predominant in the gaseous phase (Spearman correlation, $p<0.05$; Table S16). Effective wet scavenging of Phe, Flt, and Pyr has been suggested earlier (Škrdlíková et al., 2011). Furthermore, a strong negative correlation with the mass of water vapour in the air (specific humidity) was determined for most of the compounds (Spearman correlation, $p<0.05$;
Table S17). Particle-associated HMW compounds are readily scavenged by precipitation, while water solubility and polarity (for nitro- and oxy-PAHs) play an additional role in wet scavenging processes (Shahpoury et al., 2018). The gas phase removal from the atmosphere is due to substance dissolution in water droplets, which enhances the scavenging effect at higher humidity. A higher sensitivity of gas scavenging com- 
pared with particle scavenging towards liquid water content was also indicated by Škrdlíková et al. (2011).

In general, the obtained \%PM was in agreement with those reported earlier (Table S18). A higher \%PM of 9,10-AntQ and several nitro-PAHs (1- and 2-NNap, 2-NFlu, 9-NAnt, 9NPhen) was detected in French Alpine sites in winter (Albinet et al., 2008), while a higher \%PM of Flt, 9-Flu, and cPPhen-4 found in the present study contrasts with those reported for temperate urban and rural sites in China and Europe (B. Huang et al., 2014; Tomaz et al., 2016). Source difference, weather influence such as precipitation and temperature, and different atmospheric conditions (e.g. number of suspended particles, mass size particle distribution, and specific humidity) are likely responsible for these variations.

\section{Source identification}

Due to changes in the Arctic front, more frequent precipitation, and low levels of wood and coal burning for residential heating in the Northern Hemisphere in the summer, the LRAT of PAHs to the Arctic is low in summer. Sampling was performed on days with predicted northwesterly wind, and according to the $5 \mathrm{~d}$ back-trajectory analysis, the air arriving to Longyearbyen in the sampling period mainly came from the north and from Greenland (Fig. S4). As discussed in Sect. 3.2.1, up to 2 orders of magnitude lower PAH concentrations were detected at the Zeppelin monitoring station compared to the levels in Longyearbyen at the same time. Thus, local emissions were the main sources of PAHs in Longyearbyen in this study.

Besides the PP emission, vehicles are another obvious local source of PAHs. In 2018, 1558 vehicles, including cars, lorries, and buses, were registered in Longyearbyen (Table S19; Statistics Norway, 2018). Longyearbyen maintains about $50 \mathrm{~km}$ of paved and unpaved roads dedicated to traffic (Bore, 2012). Sampling was conducted at the end of summer in order to avoid peak emissions from marine traffic and to focus on PP emissions; however, it is likely that some of the 718 registered private boats were active in Adventfjørd and several larger ocean-going vessels were in the port around the sampling period (weeks 34-38, Fig. S5). Thus, shipping emissions could not be eliminated as a potential source of PAHs. Note that there is no local waste incineration and wood burning.

PCA was applied to samples from Adventdalen $(n=6)$ and UNIS $(n=6)$ to determine potential PAH sources in each location. Total PAH $(\mathrm{G}+\mathrm{P})$ concentrations were used to minimize the influence of partitioning, ageing, and photochemical degradation. Selected PAH diagnostic ratios (Table 3) and weather parameters were utilized as additional supportive tools for sources interpretation, and their values were used as variables. Diagnostic ratios may be affected by large-scale mixing of PAHs in the atmosphere, differing emission rates of PAH from the same source, the in- fluence of changing environmental conditions, and the atmospheric processing of individual PAH compounds with different atmospheric lifetimes and reactivities (Alam et al., 2013; Tobiszewski and Namieśnik, 2012; Katsoyiannis and Breivik, 2014). Ratios based on highly reactive compounds such as Ant and BaAnt were not included, while more stable HMW PAHs diagnostic ratios were interpreted with greater confidence (Galarneau, 2008; Alam et al., 2014). Yunker et al. (2002) previously proposed the ratio of IPyr / (IPyr+BPer) to differentiate vehicle from coal combustion emissions. BbkFlt / BPer was selected as an additional marker ratio for traffic due to the greater capacity to discriminate between diesel and gasoline emissions, as well as due to its wider value range (Kuo et al., 2013). The Flt / (Flt+Pyr) ratio is often used for source identification and, in particular, to understand if PAHs are mainly emitted from petroleum sources or from combustion processes (Yu et al., 2019). The Flu / (Flu+Pyr) ratio was selected as a specific indicator for coal combustion due to its strong correlation with the local PP determined markers, and the ratio value was also in agreement with the literature (Yunker et al., 2002; Katsoyiannis and Breivik, 2014). Two principal components (PCs) for Adventdalen (74\%) and two PCs for UNIS (74\%) were focused on.

\subsection{Adventdalen}

The first and the second PCs described $51 \%$ and $23 \%$ of the total variance, respectively (Table S20). Three groups of compounds suggest three different potential sources. The first group include Flt, Pyr, cPPhe-4, BaFlu-11, and BaAnt7,12. Strong correlations between their concentrations and the IPyr / (IPyr+BPer) ratio suggest a traffic origin for these compounds (Yunker et al., 2002) and specifically diesel emissions (Tables 3; S21; Ravindra et al., 2006, 2008a). Because of the rural position, car traffic is much lower at this location. At the same time, due to the proximity to an active mine (Fig. 1), heavy-duty vehicles (coal trucks, tourist buses, geotechnical drilling machinery) are thus the main candidate source for PAH vehicle emissions. Produced coal is regularly delivered from the mine to PP and storage area in the harbour on a road situated $150 \mathrm{~m}$ away from the Adventdalen sampling station. Coal is transported by Volvo FH540 trucks (built in 2018-2020) driven on diesel CFPP-12 (NSEN 590; Per Nilssen, Store Norske, personal communication, 2020; Table S23). The trucks have Euro 6 standard compliant Volvo D13K engines (HC 0.13, CO 1.5, $\mathrm{NO}_{x} 0.4, \mathrm{PM}$

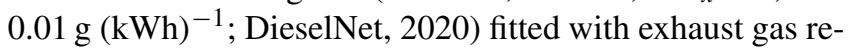
circulation, diesel particulate filter, diesel oxidation catalyst, selective catalytic reduction, and ammonia oxidation catalyst (Volvo Trucks, 2020). These allow high operation temperatures and high efficiencies in reducing particle and $\mathrm{NO}_{x}$ emissions. Numerous studies showed substantial reduction in gaseous and particulate emissions of PAH and nitro- and oxyPAHs as the result of such mitigation in particle and $\mathrm{NO}_{x}$ 
emissions (Hu et al., 2013; Gerald Liu et al., 2010; Khalek et al., 2015; Huang et al., 2015). An up to 10 orders of magnitude reduction in emission from similar to Volvo D13K heavy-duty engine was reported for several nitro-PAHs (6NChry, 1-NPyr, 2-NPyr, 4-NPyr, 7-NBaAnt; Liu et al., 2015; Gerald Liu et al., 2010), which were not detected in the present study, most likely due to low vehicle numbers in Adventdalen. However, Flt, Phe, and Pyr have been widely reported to be emitted after diesel emissions (Albinet et al., 2007; Ravindra et al., 2008a; Wingfors, 2001) as have BaFlu11, BaAnt-7,12, and cPPhen (Nyström et al., 2016; Ahmed et al., 2018; Rogge et al., 1993). 9-Flu, 9,10-AntQ, and 1-NNap were the main oxy- and nitro-PAHs emitted from modern technology heavy-duty diesel engines (Liu et al., 2015; Gerald Liu et al., 2010; Guan et al., 2017), supporting the traffic origin of the group 1 compounds too.

9-Flu, 9,10-AntQ, and 1-NNap, together with Phe and Flu (group 2), seem to have a double origin. On a PCA loading plot these compounds have a similar proximity to the traffic emission ratio (PC1), as well as to the coal combustion ratio (PC2). As reported earlier, Phe, Flu, 9,10-AntQ, 9-Flu, and 1-NNap together accounted for $74 \%$ of the total PAH emission from the local PP (Fig. 2) and a Mann-Whitney $U$ statistical test $(n=6, p \leq 0.05)$ showed no significant difference between values of the Flu / (Flu+Pyr) coal combustion diagnostic ratio based on the measured Flu and Pyr concentrations in Adventdalen and in the local PP stack emission.

The PC1 emphasized a positive correlation of $2+3-\mathrm{NFlt}$ and 9-NAnt (group 3) with temperature, humidity, and UV radiation, as well as a negative correlation with primary PAHs (Fig. 4, Table S17), suggesting a secondary source of origin. The daughter-to-parent PAH ratios, 9-NAnt/Ant and $2+3$-NFlt / Flt (Table S24), showed statistically significant correlations with temperature, humidity, and UV radiation (Spearman correlation, $p<0.10$; Table S25). Moreover, $2+3$-NFlt and 9-NAnt had a strong positive correlation with each other and negatively correlated with their parent compounds (Spearman correlation, Table S26), by reason of assumed chemical transformation. It should be noted that 9NAnt and 2+3-NFlt were detected in the PP flue gas at low levels ( 0.08 and $0.5 \mathrm{ng} \mathrm{m}^{-3}$, respectively), and further statistical analysis (Spearman correlation, Table S26, Fig. 4) showed no correlation with established PP tracers (Phe, 9,10AntQ, and 9-Flu), suggesting a different source of origin. These results indicate atmospheric formation as an additional source of 9-NAnt and 2+3-NFlt, in agreement with other studies (Lin et al., 2015; Hayakawa et al., 2000; Shahpoury et al., 2018). Sampling close to a major source of $\mathrm{NO}_{x}$ emission such as the local power plant can result in concentrations of $\mathrm{NO}_{3}$ and $\mathrm{NO}_{2}$ at high enough levels for atmospheric transformation of PAHs to occur (Keyte et al., 2013). Relative contribution of primary and secondary sources of nitroPAHs could be evaluated by applying a 2-NFlt / 1-NPyr ratio (Ringuet et al., 2012; Ciccioli et al., 1996), but 1-NPyr was not detected in our study.

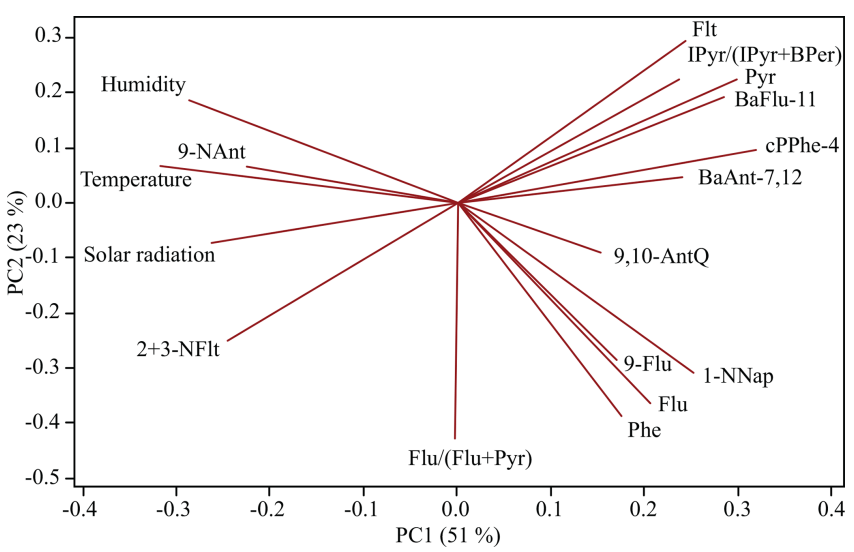

Figure 4. Principal component analysis loading plot of $\mathrm{PC} 1$ and $\mathrm{PC} 2$ for Adventdalen samples $(\mathrm{G}+\mathrm{P} ; n=6)$.

The two PCs explain $74 \%$ of the total variance. Traffic emission (mainly diesel exhaust) and the coal burning PP are concluded as the main local sources of PAHs and nitro- and oxy-PAHs in Adventdalen, and atmospheric transformation of PAHs is an additional source of nitro-PAHs.

\subsection{UNIS}

The proximity of the UNIS sampling location to central Longyearbyen, as well as to the PP and the port, makes the UNIS location more complex for source identification. This site is mainly influenced by passenger car traffic, although heavy-duty vehicles also pass UNIS. Overall, 1114 private cars were registered in Longyearbyen in 2018 (Statistics Norway, 2018), including old- and modern-technology cars (Euro 3-7 emission standard), approximately equally balanced between gasoline and diesel fuel. Gasoline 95 (with up to $5 \%$ bioethanol) and diesel CFPP-12 (with up to $7 \%$ biodiesel) are the exclusive fuels used in summer time and comply with the Norwegian standard NS-EN 228 and NS-EN 590 , respectively, with ultra-low $(<10 \mathrm{ppm}$ or $0.001 \%)$ sulfur content (Jøran Storø, LNS Spitsbergen, personal communication, 2020). Details of the fuel parameters can be found in Tables S22 and S23.

Muñoz et al. (2018) undertook a study under similar vehicle and fuel conditions to Longyearbyen and reported a predominance of LMW PAHs for both fuels. Flt, Pyr, and Phe and BPer, BaPyr, Chry, and BbFlt were found to be the most abundant compounds in gaseous and particulate phases, respectively, in agreement with earlier studies (Nyström et al., 2016). A similar PAH pattern was found for UNIS samples. On the PCA plot (Fig. 5) Flt, Pyr, BPer, BaPyr, Chry, and BbkFlt are grouped together (group 1) and have equally high loadings on the PC1 (Table S27). The compound concentrations are significantly correlated with the traffic ratio BbkFlt / BPer $(p<0.05$, Table S28) suggesting the same origin of the compounds. The BbkFlt / BPer ratio varied from 


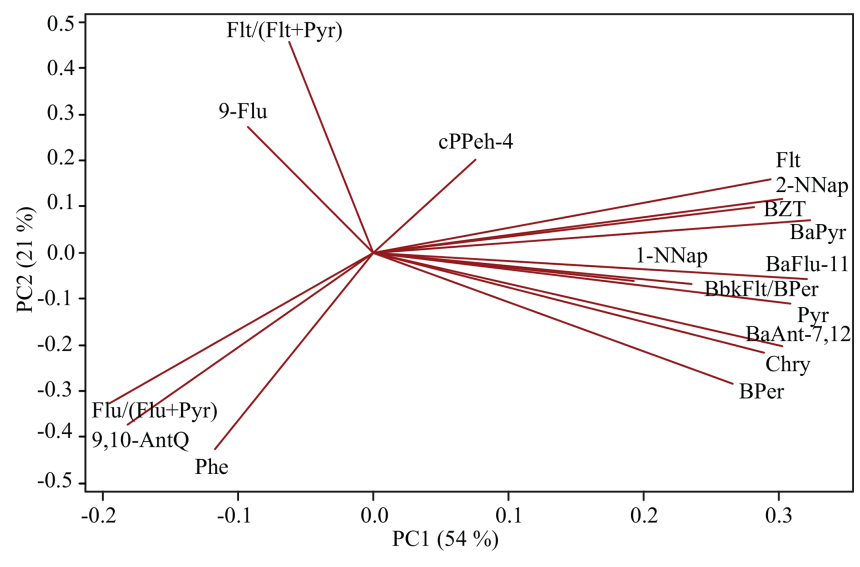

Figure 5. Principal component analysis loading plot of PC1 and PC2 for UNIS samples $(\mathrm{G}+\mathrm{P} ; n=6)$.

0.43 to 0.72 indicating either diesel or gasoline emissions (Kuo et al., 2013). The diesel emission predominance was found for 2 out of the 6 sampling days, although particulate phase 1-NPyr, a marker of diesel emissions, was not detected. 1-NPyr forms in the combustion chamber of diesel engines by the addition of nitrogen oxide or nitrogen dioxide to free Pyr radicals (IARC, 2014). Its generation is facilitated by the high engine temperatures (IARC, 2014; Karavalakis et al., 2010; Guan et al., 2017; Huang et al., 2015), which likely cannot be reached in Longyearbyen due to short driving distances and a low speed limit. The use of high-quality ultralow sulfur fuel with substantially reduced emissions of $\mathrm{NO}_{x}$ leads to reduced nitration of PAHs during fuel combustion (Heeb et al., 2008; T. Zhao et al., 2020) and together with low total vehicle number results in low nitro-PAH emissions. The atmospheric deposition which occurred may be of influence too.

Gaseous phase 1-NNap and 2-NNap have large loadings on the PC1. They are often reported in traffic emissions (Alam et al., 2015; Albinet et al., 2007; Keyte et al., 2016), as well as oxy-PAHs such as BaFlu-11, BaAnt-7,12, and BZT (Nyström et al., 2016; Albinet et al., 2007; Ahmed et al., 2018; Karavalakis et al., 2010). All these nitro- and oxyPAHs have a strong positive correlation with the traffic ratio (Table S28). Thus, we conclude the traffic (diesel and gasoline) is the source for Flt, Pyr, Chry, BPer, BaPyr, 1-NNap, 2-NNap, BaFlu-11, BaAnt-7,12, and BZT at the UNIS location.

A second group of compounds (Phe, Flu, and 9,10AntQ) was strongly correlated with the coal combustion ratio Flu / (Flu+Pyr) (Fig. 5, Table S28), supported by their predominance (along with 9-Flu) in the PP emissions (Fig. 2). 9-Flu may have other possible sources, including diesel and gasoline vehicle exhaust, coal powder, and road dust particles (Keyte et al., 2013), and may be locally produced, transported a longer range, or secondarily formed in the atmosphere (Kojima et al., 2010). Interestingly, despite heavy rain during sampling, 9-Flu was found in its maximum concentration (about 2-fold higher the average detected level) on the second sampling day, which may suggest a strong local emission on that day in addition to the daily PP emissions. 9-Flu showed a strong positive correlation with the Flt / (Flt+Pyr) ratio, indicating petrol or marine fuel sources (Zhang et al., 2019). The ratio did not correlate with the traffic-emitted compounds and the traffic ratio (group 1); thus marine fuel emission was regarded as a potential source. Despite the intention to collect air samples at the end of summer to avoid the peak marine traffic, four large boats (fishing, two cruise vessels, and oil tanker; Fig. S5) and some private boats were registered in Longyearbyen harbour during sampling day 2 (Kystdatahuset, 2018). Our assumption is supported by reports of 9-Flu, cPPhen-4, and 9,10-AntQ as major oxy-PAHs in ship emissions (Czech et al., 2017; J. Zhao et al., 2020, 2019). According to Svalbard environmental law, vessels entering Svalbard coastal waters are required to use distillate marine fuel (DMA ISO 8217:2017) instead of heavy marine oil to satisfy regulations requiring a fuel sulfur content below $1.0 \%$ (Governor of Svalbard, 2014). Ultra-low sulfur diesel CFPP-12 (NS-EN 590, with sulfur content below $0.001 \%$, Table S23) is also used for private boats. Such predominance of distillate marine diesel explains the strong correlation of 9-Flu with the marine fuel ratio and no correlation with 9,10AntQ, which is mainly emitted from heavy-fuel oil (Huang et al., 2018). The use of high-quality fuels decreases the emissions of particles (Anderson et al., 2015). A reduction of up to $94 \%$ particulate PAH emission was reported when burning low-sulfur fuel compared to heavy-fuel oil (Huang et al., 2018; Gregoris et al., 2016; Kotchenruther, 2017; Czech et al., 2017). This explains the absence of particle-bound PAHs correlating with the marine ratio Flt / (Flt+Pyr).

The two PCs explain $74 \%$ of the total variance of the UNIS samples. PP coal burning, traffic, and marine shipping emissions are determined as potential sources of PAHs and nitro- and oxy-PAHs.

\section{Conclusions}

The results provide insights into local sources of atmospheric PAHs and nitro- and oxy-PAHs in Svalbard. Source markers for the coal burning PP in Longyearbyen were determined, and generally low emissions of PAHs confirmed an efficient exhaust cleaning system. However, PAHs are emitted daily from coal burning and, due to a large volume of flue gas emissions, the PP remains an important local anthropogenic source of atmospheric contaminants. Overall, nitroand oxy-PAH concentrations were the same order of magnitude as detected at other background Scandinavian and European air sampling stations, and PAHs were 1 order of magnitude higher than in Ny-Ålesund, Svalbard. The gas-particle partitioning of PAHs and nitro- and oxy-PAHs was dependent on air temperature and humidity and mainly impacted 
semi-volatile compounds with three and four aromatic rings. Vehicle and marine traffic were other contributors to PAH emissions. The results also revealed secondary atmospheric formation as an additional source of 2+3-NFlt and 9-NAnt. The present study contributes to understanding the fate and distribution of PAHs in the Arctic, and it provides important information on the phase-separated concentrations of PAHs and nitro- and oxy-PAHs in Arctic air, as well as markers of the Longyearbyen PP emissions. This data can eliminate uncertainties in model predictions that aim to assess the extent and impacts of Arctic atmospheric contaminants. Furthermore, the knowledge on local emissions level can be important in case of temperature inversion in the lower atmosphere when vertical dilution is limited and contaminants are trapped near the ground, which may be adverse to public health.

Data availability. The dataset used in this paper is included in the Supplement, and further information is available from the corresponding author at tatiana.drotikova@unis.no.

Supplement. The supplement related to this article is available online at: https://doi.org/10.5194/acp-20-9997-2020-supplement.

Author contributions. RK, AKH, and HCR designed the campaign. TD conducted the field and lab works. TD, with support from AMA and RK, optimized, validated, and performed GC analysis and further quantification. TD processed and interpreted PCA outcome. TD prepared the paper with contributions from all co-authors. TD, AMA, and AKH prepared the Supplement.

Competing interests. The authors declare that they have no conflict of interest.

Acknowledgements. We gratefully acknowledge Longyearbyen Lokalstyre (Longyearbyen Community Council), specifically Kim Rune Røkenes (a former leader of Energyverket), for the support in performing the PP exhaust sampling. We also thank Rasmus Bøckman (Lokalstyre, Energyverket) for providing information on the PP system operating parameters; Morten Hogsnes and Kristin Lundgjerdingen (Applica Test \& Certification AS) for sharing their knowledge on PP flue gas sampling; Siiri Wickström (UNIS) for helping with weather prediction; Marcos Porcires (UNIS) for on-site installation of weather station; Øyvind Mikkelsen (Norwegian University of Science and Technology) for teaching on the PCA topic; and Malte Jochmann (UNIS/Store Norske) for fruitful discussions on Svalbard coal quality. This research was financially supported by UNIS, NMBU, and the Svalbard Environmental Protection Fund (AtmoPart project).
Financial support. This research has been supported by the Svalbard Environmental Protection Fund (grant no. 940010).

Review statement. This paper was edited by Ralf Ebinghaus and reviewed by two anonymous referees.

\section{References}

Ahmed, T. M., Bergvall, C., and Westerholm, R.: Emissions of particulate associated oxygenated and native polycyclic aromatic hydrocarbons from vehicles powered by ethanol/gasoline fuel blends, Fuel, 214, 381-385, https://doi.org/10.1016/j.fuel.2017.11.059, 2018.

Alam, M. S., Delgado-Saborit, J. M., Stark, C., and Harrison, R. M.: Using atmospheric measurements of PAH and quinone compounds at roadside and urban background sites to assess sources and reactivity, Atmos. Environ., 77, 24-35, https://doi.org/10.1016/j.atmosenv.2013.04.068, 2013.

Alam, M. S., Delgado-Saborit, J. M., Stark, C., and Harrison, R. M.: Investigating PAH relative reactivity using congener profiles, quinone measurements and back trajectories, Atmos. Chem. Phys., 14, 2467-2477, https://doi.org/10.5194/acp-142467-2014, 2014.

Alam, M. S., Keyte, I. J., Yin, J., Stark, C., Jones, A. M., and Harrison, R. M.: Diurnal variability of polycyclic aromatic compound (PAC) concentrations: Relationship with meteorological conditions and inferred sources, Atmos. Environ., 122, 427-438, https://doi.org/10.1016/j.atmosenv.2015.09.050, 2015.

Albinet, A., Leoz-Garziandia, E., Budzinski, H., and Viilenave, E.: Polycyclic aromatic hydrocarbons (PAHs), nitrated PAHs and oxygenated PAHs in ambient air of the Marseilles area (South of France): Concentrations and sources, Sci. Total Environ., 384, 280-292, https://doi.org/10.1016/j.scitotenv.2007.04.028, 2007.

Albinet, A., Leoz-Garziandia, E., Budzinski, H., Villenave, E., and Jaffrezo, J. L.: Nitrated and oxygenated derivatives of polycyclic aromatic hydrocarbons in the ambient air of two French alpine valleys. Part 1: Concentrations, sources and gas/particle partitioning, Atmos. Environ., 42, 43-54, https://doi.org/10.1016/j.atmosenv.2007.10.009, 2008.

Albinet, A., Tomaz, S., and Lestremau, F.: A really quick easy cheap effective rugged and safe (QuEChERS) extraction procedure for the analysis of particle-bound PAHs in ambient air and emission samples, Sci. Total Environ., 450-451, 31-38, https://doi.org/10.1016/j.scitotenv.2013.01.068, 2013.

Albinet, A., Nalin, F., Tomaz, S., Beaumont, J., and Lestremau, F.: A simple QuEChERS-like extraction approach for molecular chemical characterization of organic aerosols: application to nitrated and oxygenated PAH derivatives (NPAH and OPAH) quantified by GC-NICIMS, Anal. Bioanal. Chem., 406, 3131-3148, https://doi.org/10.1007/s00216-014-7760-5, 2014.

Anderson, M., Salo, K., Hallquist, A. M., and Fridell, E.: Characterization of particles from a marine engine operating at low loads, Atmos. Environ., 101, 65-71, https://doi.org/10.1016/j.atmosenv.2014.11.009, 2015.

Armitage, J. M., Quinn, C. L., and Wania, F.: Global climate change and contaminants-an overview of opportunities and priorities for modelling the potential implications for long-term human expo- 
sure to organic compounds in the Arctic, J. Environ. Monitor., 13, 1532-1546, https://doi.org/10.1039/c1em10131e, 2011.

Balmer, J. and Muir, D.: Polycyclic aromatic hydrocarbons (PAHs), in: AMAP Assessment 2016: Chemicals of emerging Arctic concern, edited by: Hung, H., Letcher, R., and Yu, Y., Arctic Monitoring and Assessment Programme (AMAP), Oslo, Norway, 219-238, 2017.

Barrie, L. A., Gregor, D., Hargrave, B., Lake, R., Muir, D., Shearer, R., Tracey, B., and Bidleman, T.: Arctic contaminants: Sources, occurrence and pathways, Sci. Total Environ., 122, 174, https://doi.org/10.1016/0048-9697(92)90245-n, 1992.

Bøckman, R.: Fremtidens energiutfordringer på Svalbard (in Norwegian), Longyearbyen Lokalstyre, Norway, 10 pp., available at: https://www.uit.no (last access: 28 January 2020), 2019.

Bore, R. R., Andreassen, I., Kristiansen, J. E., and Modig, I.: Dette er Svalbard 2012. Hva tallene forteller, Statistics Norway, Oslo, Norway, 24 pp., 2012 (in Norwegian).

Bradley, R. S., Keimig, F. T., and Diaz, H. F.: Climatology of surface-based inversions in the North American Arctic, J. Geophys. Res., 97, 15699, https://doi.org/10.1029/92JD01451, 1992.

Brorström-Lundén, E., Remberger, M., Kaj, L., Hansson, K., Palm Cousins, A., and Andersson, H.: Results from the Swedish national screening programme 2008, IVL Swedish Environmental Research Institute, Göteborg, Sweden, 69 pp., 2010.

Brubaker, W. W. and Hites, R. A.: OH reaction kinetics of polycyclic aromatic hydrocarbons and polychlorinated dibenzo-pdioxins and dibenzofurans, J. Phys. Chem. A, 102, 915-921, https://doi.org/10.1021/jp9721199, 1998.

Ciccioli, P., Cecinato, A., Brancaleoni, E., Frattoni, M., Zacchei, P., Miguel, A. H., and De Castro Vasconcellos, P.: Formation and transport of 2-nitrofluoranthene and 2-nitropyrene of photochemical origin in the troposphere, J. Geophys. Res., 101, 1956719581, https://doi.org/10.1029/95jd02118, 1996.

Czech, H., Stengel, B., Adam, T., Sklorz, M., Streibel, T., and Zimmermann, R.: A chemometric investigation of aromatic emission profiles from a marine engine in comparison with residential wood combustion and road traffic: Implications for source apportionment inside and outside sulphur emission control areas, Atmos. Environ., 167, 212-222, https://doi.org/10.1016/j.atmosenv.2017.08.022, 2017.

Dekhtyareva, A., Edvardsen, K., Holmén, K., Hermansen, O., and Hansson, H. C.: Influence of local and regional air pollution on atmospheric measurements in Ny-Ålesund, Int. J. Sust. Dev. Plan., 11, 578-587, https://doi.org/10.2495/sdp-v11-n4-578-587, 2016.

DieselNet: EU emission standards for heavy-duty truck and bus engines: available at: https://www.dieselnet.com/standards/, last access: 5 June 2020.

Durant, J. L., Busby Jr., W. F., Lafleur, A. L., Penman, B. W., and Crespi, C. L.: Human cell mutagenicity of oxygenated, nitrated and unsubstituted polycyclic aromatic hydrocarbons associated with urban aerosols, Mutat. Res.-Genet. Tox., 371, 123157, https://doi.org/10.1016/S0165-1218(96)90103-2, 1996.

Esau, I., Argentini, S., Przybylak, R., Repina, I., and Sjöblom, A.: Svalbard Meteorology, Adv. Meteorol., 2012, 818473, https://doi.org/10.1155/2012/818473, 2012.

EU Directive 2004/107/EC: Directive 2004/107/EC of the European Parliament and the Council of 15 December 2004 relating to arsenic, cadmium, mercury, nickel and polycyclic aromatic hy- drocarbons in ambient air, in: Official Journal of the European Union, 2005.

Fiedler, H., Kallenborn, R., Boer, J. D., and Sydnes, L. K.: The Stockholm Convention: A tool for the global regulation of persistent organic pollutants, Chem. Int., 41, 4-11, https://doi.org/10.1515/ci-2019-0202, 2019.

Finlayson-Pitts, B. J. and Pitts Jr., J. N.: Chemistry of the upper and lower atmosphere: theory, experiments, and applications, Elsevier, 1999.

Franklin, J. A., Atkinson, R., Howard, P. H., Orlando, J. J., Seigneur, C., Wallington, T. J., and Zetzsch, C.: Quantitative determination of persistence in air, in: Evaluation of persistence and long-range transport of chemicals in the environment, edited by: Klečka, G. M., Mackay, D., Boethling, R. S., Calamari, D., CowanEllsberry, C., Eisenreich, S., Franklin, J., Grady Jr., C. P. L., Graham, D. G., Hansen, B., Howard, P. H., Jones, K. C., Kannan, K., Larson, R. J., Macdonald, R. W., McKone, T., Muir, D., Parkerton, T., Thibodeaux, L., van de Meent, D., Wallington, T., and Zetzsch, C., SETAC Press, Pensacola, Florida, USA, 7-62, 2000.

Friedman, C. L. and Selin, N. E.: Long-range atmospheric transport of polycyclic aromatic hydrocarbons: a global 3-D model analysis including evaluation of Arctic sources, Environ. Sci. Technol., 46, 9501-9510, https://10.1021/es301904d, 2012.

Friedman, C. L., Zhang, Y., and Selin, N. E.: Climate change and emissions impacts on atmospheric PAH transport to the Arctic, Environ. Sci. Technol., 48, 429-437, https://doi.org/10.1021/es403098w, 2014.

Fu, P., Kawamura, K., Chen, J., and Barrie, L. A.: Isoprene, monoterpene, and sesquiterpene oxidation products in the high Arctic aerosols during late winter to early summer, Environ. Sci. Technol., 43, 4022-4028, https://doi.org/10.1021/es803669a, 2009.

Galarneau, E.: Source specificity and atmospheric processing of airborne PAHs: Implications for source apportionment, Atmos. Environ., 42, 8139-8149, https://doi.org/10.1016/j.atmosenv.2008.07.025, 2008.

Gerald Liu, Z., Berg, D. R., Vasys, V. N., Dettmann, M. E., Zielinska, B., and Schauer, J. J.: Analysis of $\mathrm{C}_{1}, \mathrm{C}_{2}$, and $\mathrm{C}_{10}$ through $\mathrm{C}_{33}$ particle-phase and semi-volatile organic compound emissions from heavy-duty diesel engines, Atmos. Environ., 44, 1108-1115, https://doi.org/10.1016/j.atmosenv.2009.11.036, 2010.

Governor of Svalbard: Heavy fuel oil ban in the protected areas of Svalbard, available at: https://www.sysselmannen no/en/heavy-fuel-oil-ban-in-the-protected-areas/ (last access: 5 June 2020), 2014.

Gregoris, E., Barbaro, E., Morabito, E., Toscano, G., Donateo, A., Cesari, D., Contini, D., and Gambaro, A.: Impact of maritime traffic on polycyclic aromatic hydrocarbons, metals and particulate matter in Venice air, Environ. Sci. Pollut. Res., 23, 69516959, https://doi.org/10.1007/s11356-015-5811-x, 2016.

Guan, C., Cheung, C. S., Li, X., and Huang, Z.: Effects of oxygenated fuels on the particle-phase compounds emitted from a diesel engine, Atmos. Pollut. Res., 8, 209-220, https://doi.org/10.1016/j.apr.2016.08.005, 2017.

Hayakawa, K., Murahashi, T., Akutsu, K., Kanda, T., Tang, N., Kakimoto, H., Toriba, A., and Kizu, R.: Comparison of polycyclic aromatic hydrocarbons and nitropoly- 
cyclic aromatic hydrocarbons in airborne and automobile exhaust particulates, Polycycl. Aromat. Comp., 20, 179-190, https://doi.org/10.1080/10406630008034784, 2000.

Heeb, N. V., Schmid, P., Kohler, M., Gujer, E., Zennegg, M., Wenger, D., Wichser, A., Ulrich, A., Gfeller, U., Honegger, P., Zeyer, K., Emmenegger, L., Petermann, J.-L., Czerwinski, J., Mosimann, T., Kasper, M., and Mayer, A.: Secondary effects of catalytic diesel particulate filters: conversion of PAHs versus formation of nitro-PAHs, Environ. Sci. Technol., 42, 3773-3779, https://doi.org/10.1021/es7026949, 2008.

Holmes, D., Moody, P., Dine, D., and Trueman, L.: Research methods for the biosciences, Third ed., Oxford University Press, Oxford, United Kingdom, 2017.

Hsu, W. T., Liu, M. C., Hung, P. C., Chang, S. H., and Chang, M. B.: PAH emissions from coal combustion and waste incineration, J. Hazard. Mater., 318, 32-40, https://doi.org/10.1016/j.jhazmat.2016.06.038, 2016.

Hu, H., Tian, M., Zhang, L., Yang, F., Peng, C., Chen, Y., Shi, G., Yao, X., Jiang, C., and Wang, J.: Sources and gas-particle partitioning of atmospheric parent, oxygenated, and nitrated polycyclic aromatic hydrocarbons in a humid city in southwest China, Atmos. Environ., 206, 1-10, https://doi.org/10.1016/j.atmosenv.2019.02.041, 2019.

Hu, S., Herner, J. D., Robertson, W., Kobayashi, R., Chang, M. C. O., Huang, S.-M., Zielinska, B., Kado, N., Collins, J. F., Rieger, P., Huai, T., and Ayala, A.: Emissions of polycyclic aromatic hydrocarbons (PAHs) and nitro-PAHs from heavy-duty diesel vehicles with DPF and SCR, J. Air Waste Manage., 63, 984-996, https://doi.org/10.1080/10962247.2013.795202, 2013.

Huang, B., Liu, M., Bi, X., Chaemfa, C., Ren, Z., Wang, X., Sheng, G., and Fu, J.: Phase distribution, sources and risk assessment of PAHs, NPAHs and OPAHs in a rural site of Pearl River Delta region, China, Atmos. Pollut. Res., 5, 210-218, https://doi.org/10.5094/APR.2014.026, 2014.

Huang, C., Hu, Q., Wang, H., Qiao, L., Jing, S. a., Wang, H., Zhou, M., Zhu, S., Ma, Y., Lou, S., Li, L., Tao, S., Li, Y., and Lou, D.: Emission factors of particulate and gaseous compounds from a large cargo vessel operated under real-world conditions, Environ. Pollut., 242, 667-674, https://doi.org/10.1016/j.envpol.2018.07.036, 2018.

Huang, L., Bohac, S. V., Chernyak, S. M., and Batterman, S. A.: Effects of fuels, engine load and exhaust after-treatment on diesel engine SVOC emissions and development of SVOC profiles for receptor modeling, Atmos. Environ., 102, 228-238, https://doi.org/10.1016/j.atmosenv.2014.11.046, 2015.

Huang, W., Huang, B., Bi, X., Lin, Q., Liu, M., Ren, Z., Zhang, G., Wang, X., Sheng, G., and Fu, J.: Emission of PAHs, NPAHs and OPAHs from residential honeycomb coal briquette combustion, Energ. Fuel., 28, 636-642, https://doi.org/10.1021/ef401901d, 2014.

IARC: Diesel and gasoline engine exhausts and some nitroarenes. 1-Nitropyrene, IARC Monographs on the Evaluation of Carcinogenic Risks to Humans, International Agency for Research on Cancer, Lyon, France, 2014.

Janhall, S., Olofson, K., Andersson, P., Pettersson, J., and Hallquist, M.: Evolution of the urban aerosol during winter temperature inversion episodes, Atmos. Environ., 40, 5355-5366, https://doi.org/10.1016/j.atmosenv.2006.04.051, 2006.
Jörundsdóttir, H. Ó., Jensen, S., Hylland, K., Holth, T. F., Gunnlaugsdóttir, H., Svavarsson, J., Ólafsdóttir, Á., El-Taliawy, H., Rigét, F., Strand, J., Nyberg, E., Bignert, A., Hoydal, K. S., and Halldórsson, H. P.: Pristine Arctic: background mapping of PAHs, PAH metabolites and inorganic trace elements in the North-Atlantic Arctic and sub-Arctic coastal environment, Sci. Total Environ., 493, 719-728, https://doi.org/10.1016/j.scitotenv.2014.06.030, 2014.

Karavalakis, G., Stournas, S., Ampatzoglou, D., Bakeas, E., and Spanos, A.: Regulated and unregulated emissions of a Euro 4 SUV operated with diesel and soy-based biodiesel blends, SAE Int. J. Fuels Lubr., 2, 115-131, 2010.

Katsoyiannis, A. and Breivik, K.: Model-based evaluation of the use of polycyclic aromatic hydrocarbons molecular diagnostic ratios as a source identification tool, Environ. Pollut., 184, 488-494, https://doi.org/10.1016/j.envpol.2013.09.028, 2014.

Kavouras, I. G., Koutrakis, P., Tsapakis, M., Lagoudaki, E., Stephanou, E. G., Von Baer, D., and Oyola, P.: Source apportionment of urban particulate aliphatic and polynuclear aromatic hydrocarbons (PAHs) using multivariate methods, Environ. Sci. Technol., 35, 2288-2294, https://doi.org/10.1021/es001540z, 2001.

Keyte, I. J., Harrison, R. M., and Lammel, G.: Chemical reactivity and long-range transport potential of polycyclic aromatic hydrocarbons - a review, Chem. Soc. Rev., 42, 9333-9391, https://doi.org/10.1039/C3CS60147A, 2013.

Keyte, I. J., Albinet, A., and Harrison, R. M.: On-road traffic emissions of polycyclic aromatic hydrocarbons and their oxy- and nitro- derivative compounds measured in road tunnel environments, Sci. Total Environ., 566-567, 1131-1142, https://doi.org/10.1016/j.scitotenv.2016.05.152, 2016.

Khalek, I. A., Blanks, M. G., Merritt, P. M., and Zielinska, B.: Regulated and unregulated emissions from modern 2010 emissions-compliant heavy-duty on-highway diesel engines, J. Air Waste Manage., 65, 987-1001, https://doi.org/10.1080/10962247.2015.1051606, 2015.

Kim, D., Kumfer, B. M., Anastasio, C., Kennedy, I. M., and Young, T. M.: Environmental aging of polycyclic aromatic hydrocarbons on soot and its effect on source identification, Chemosphere, 76, 1075-1081, https://doi.org/10.1016/j.chemosphere.2009.04.031, 2009.

Kim, K.-H., Jahan, S. A., Kabir, E., and Brown, R. J. C.: A review of airborne polycyclic aromatic hydrocarbons (PAHs) and their human health effects, Environ. Int., 60, 71-80, https://doi.org/10.1016/j.envint.2013.07.019, 2013.

Klonecki, A.: Seasonal changes in the transport of pollutants into the Arctic troposphere-model study, J. Geophys. Res., 108, 8367, https://doi.org/10.1029/2002jd002199, 2003.

Kojima, Y., Inazu, K., Hisamatsu, Y., Okochi, H., Baba, T., and Nagoya, T.: Influence of secondary formation on atmospheric occurrences of oxygenated polycyclic aromatic hydrocarbons in airborne particles, Atmos. Environ., 44, 2873-2880, https://doi.org/10.1016/j.atmosenv.2010.04.048, 2010.

Kotchenruther, R. A.: The effects of marine vessel fuel sulfur regulations on ambient $\mathrm{PM}_{2.5}$ at coastal and near coastal monitoring sites in the U.S, Atmos. Environ., 151, 52-61, https://doi.org/10.1016/j.atmosenv.2016.12.012, 2017.

Kuo, C.-Y., Chien, P.-S., Kuo, W.-C., Wei, C.-T., and Rau, J.-Y.: Comparison of polycyclic aromatic hydrocarbon emis- 
sions on gasoline- and diesel-dominated routes, Environ. Monit. Assess., 185, 5749-5761, https://doi.org/10.1007/s10661-0122981-6, 2013.

Kystdatahuset: Longyearbyen port traffic for 2018: available at: https://kystdatahuset.no/ (last access: 5 June 2020), 2018.

Lammel, G.: Long-range atmospheric transport of polycyclic aromatic hydrocarbons is worldwide problem - results from measurements at remote sites and modelling, Acta Chim. Slov., 729735, https://doi.org/10.17344/acsi.2015.1387, 2015.

Lammel, G., Sehili, A. M., Bond, T. C., Feichter, J., and Grassl, H.: Gas/particle partitioning and global distribution of polycyclic aromatic hydrocarbons - A modelling approach, Chemosphere, 76, 98-106, https://doi.org/10.1016/j.chemosphere.2009.02.017, 2009.

Lammel, G., Kitanovski, Z., Kukucka, P., Novak, J., Arangio, A. M., Codling, G. P., Filippi, A., Hovorka, J., Kuta, J., Leoni, C., Pribylova, P., Prokes, R., Sanka, O., Shahpoury, P., Tong, H. J., and Wietzoreck, M.: Oxygenated and nitrated polycyclic aromatic hydrocarbons in ambient airlevels, phase partitioning, mass size distributions, and inhalation bioaccessibility, Environ. Sci. Technol., 54, 2615-2625, https://doi.org/10.1021/acs.est.9b06820, 2020.

Li, J., Li, X., Li, M., Lu, S., Yan, J., Xie, W., Liu, C., and Qi, Z.: Influence of air pollution control devices on the polycyclic aromatic hydrocarbon distribution in flue gas from an ultralowemission coal-fired power plant, Energ. Fuel., 30, 9572-9579, https://doi.org/10.1021/acs.energyfuels.6b01381, 2016.

Li, J., Chen, H., Li, Z., Wang, P., Fan, X., He, W., and Zhang, J.: Analysis of low-level temperature inversions and their effects on aerosols in the lower atmosphere, Adv. Atmos. Sci., 36, 12351250, https://doi.org/10.1007/s00376-019-9018-9, 2019.

Lin, Y., Qiu, X., Ma, Y., Ma, J., Zheng, M., and Shao, M.: Concentrations and spatial distribution of polycyclic aromatic hydrocarbons (PAHs) and nitrated PAHs (NPAHs) in the atmosphere of North China, and the transformation from PAHs to NPAHs, Environ. Pollut., 196, 164-170, https://doi.org/10.1016/j.envpol.2014.10.005, 2015.

Liu, Z. G., Wall, J. C., Ottinger, N. A., and McGuffin, D.: Mitigation of PAH and Nitro-PAH emissions from nonroad diesel engines, Environ. Sci. Technol., 49, 3662-3671, https://doi.org/10.1021/es505434r, 2015.

Lohmann, R. and Lammel, G.: Adsorptive and absorptive contributions to the gas-particle partitioning of polycyclic aromatic hydrocarbons: state of knowledge and recommended parametrization for modeling, Environ. Sci. Technol., 38, 3793-3803, https://doi.org/10.1021/es035337q, 2004.

Lundgjerdingen, K. S.: Teknisk rapport Longyearbyen Energiverket (in Norwegian), Applica Test \& Certification AS, Longyearbyen, Norway, Available by request from Longyearbyen Lokalstyre, 23, 2017.

Macdonal, R. W., Barrie, L. A., Bidleman, T. F., Diamond, M. L., Gregor, D. J., Semkin, R. G., Strachan, W. M., Li, Y. F., Wania, F., Alaee, M., Alexeeva, L. B., Backus, S. M., Bailey, R., Bewers, J. M., Gobeil, C., Halsall, C. J., Harner, T., Hoff, J. T., Jantunen, L. M., Lockhart, W. L., Mackay, D., Muir, D. C., Pudykiewicz, J., Reimer, K. J., Smith, J. N., and Stern, G. A.: Contaminants in the Canadian Arctic: 5 years of progress in understanding sources, occurrence and pathways, Sci. Total Environ., 254, 93234, https://doi.org/10.1016/s0048-9697(00)00434-4, 2000.
Macdonald, C., Lockhart, L., and Gilman, A.: Effects of oil and gas activity on the environment and human health, in: Assessment 2007: Oil and gas activities in the Arctic - effect and potential effects, Arctic Monitoring and Assessment Programme (AMAP), Oslo, Norway, 5, 1-164, 2010.

Marshall, C., Uguna, J., Large, D. J., Meredith, W., Jochmann, M., Friis, B., Vane, C., Spiro, B. F., Snape, C. E., and Orheim, A.: Geochemistry and petrology of palaeocene coals from Spitzbergen - Part 2: Maturity variations and implications for local and regional burial models, Int. J. Coal Geol., 143, 1-10, https://doi.org/10.1016/j.coal.2015.03.013, 2015.

Muñoz, M., Haag, R., Honegger, P., Zeyer, K., Mohn, J., Comte, P., Czerwinski, J., and Heeb, N. V.: Co-formation and co-release of genotoxic PAHs, alkyl-PAHs and soot nanoparticles from gasoline direct injection vehicles, Atmos. Environ., 178, 242-254, https://doi.org/10.1016/j.atmosenv.2018.01.050, 2018.

Noda, N. and Makino, H.: Influence of operating temperature on performance of electrostatic precipitator for pulverized coal combustion boiler, Adv. Powder Technol., 21, 495-499, https://doi.org/10.1016/j.apt.2010.04.012, 2010.

Nyström, R., Sadiktsis, I., Ahmed, T. M., Westerholm, R., Koegler, J. H., Blomberg, A., Sandström, T., and Boman, C.: Physical and chemical properties of RME biodiesel exhaust particles without engine modifications, Fuel, 186, 261-269, https://doi.org/10.1016/j.fuel.2016.08.062, 2016.

Onduka, T., Ojima, D., Kakuno, A., Ito, K., Koyama, J., and Fujii, K.: Nitrated polycyclic aromatic hydrocarbons in the marine environment: acute toxicities for organisms at three trophic levels, Jpn. J. Environ. Toxicol., 15, 1-10, https://doi.org/10.11403/jset.15.1, 2012.

Ontario Ministry of the Environment and Climate Change: Ontario Ambient Air Quality Criteria, available at: https://www.ontario.ca/page/ ontarios-ambient-air-quality-criteria-sorted-contaminant-name (last access: 5 June 2020), 2016.

Pedersen, H., Kallenborn, R., Ottesen, R., Gabrielsen, G., Schrum, C., Evenset, A., Ruus, A., Benjaminsen, H., Sagerup, K., and Christensen, G.: PCBs on Svalbard, Norwegian Environment Agency and Governor of Svalbard, Longyearbyen, Norway, 99 pp., 2011.

Peng, N., Li, Y., Liu, Z., Liu, T., and Gai, C.: Emission, distribution and toxicity of polycyclic aromatic hydrocarbons (PAHs) during municipal solid waste (MSW) and coal co-combustion, Sci. Total Environ., 565, 1201-1207, https://doi.org/10.1016/j.scitotenv.2016.05.188, 2016.

Ravindra, K., Bencs, L., Wauters, E., de Hoog, J., Deutsch, F., Roekens, E., Bleux, N., Berghmans, P., and Van Grieken, R.: Seasonal and site-specific variation in vapour and aerosol phase PAHs over Flanders (Belgium) and their relation with anthropogenic activities, Atmos. Environ., 40, 771-785, https://doi.org/10.1016/j.atmosenv.2005.10.011, 2006.

Ravindra, K., Sokhi, R., and Vangrieken, R.: Atmospheric polycyclic aromatic hydrocarbons: Source attribution, emission factors and regulation, Atmos. Environ., 42, 2895-2921, https://doi.org/10.1016/j.atmosenv.2007.12.010, 2008a.

Ravindra, K., Wauters, E., and Van Grieken, R.: Variation in particulate PAHs levels and their relation with the transboundary movement of the air masses, Sci. Total Environ., 396, 100-110, https://doi.org/10.1016/j.scitotenv.2008.02.018, 2008b. 
Reynaud, S. and Deschaux, P.: The effects of polycyclic aromatic hydrocarbons on the immune system of fish: A review, Aquat. Toxicol., 77, 229-238, https://doi.org/10.1016/j.aquatox.2005.10.018, 2006.

Ringuet, J., Albinet, A., Leoz-Garziandia, E., Budzinski, H., and Villenave, E.: Diurnal/nocturnal concentrations and sources of particulate-bound PAHs, OPAHs and NPAHs at traffic and suburban sites in the region of Paris (France), Sci. Total Environ., 437, 297-305, https://doi.org/10.1016/j.scitotenv.2012.07.072, 2012.

Rogge, W. F., Hildemann, L. M., Mazurek, M. A., Cass, G. R., and Simoneit, B. R.: Sources of fine organic aerosol. 2. Noncatalyst and catalyst-equipped automobiles and heavyduty diesel trucks, Environ. Sci. Technol., 27, 636-651, https://doi.org/10.1021/es00041a007, 1993.

Schmale, J., Arnold, S. R., Law, K. S., Thorp, T., Anenberg, S., Simpson, W. R., Mao, J., and Pratt, K. A.: Local Arctic air pollution: A neglected but serious problem, Earth's Future, 6, 13851412, https://doi.org/10.1029/2018ef000952, 2018.

Shahpoury, P., Lammel, G., Albinet, A., Sofuoglu, A., Dumanoglu, Y., Sofuoglu, S. C., Wagner, Z., and Zdimal, V.: Evaluation of a conceptual model for gas-particle partitioning of polycyclic aromatic hydrocarbons using poly-parameter linear free energy relationships, Environ. Sci. Technol., 50, 12312-12319, https://doi.org/10.1021/acs.est.6b02158, 2016.

Shahpoury, P., Kitanovski, Z., and Lammel, G.: Snow scavenging and phase partitioning of nitrated and oxygenated aromatic hydrocarbons in polluted and remote environments in central Europe and the European Arctic, Atmos. Chem. Phys., 18, 1349513510, https://doi.org/10.5194/acp-18-13495-2018, 2018.

Sharma, M. and McBean, E. A.: Atmospheric PAH deposition: deposition velocities and washout ratios, J. Environ. Eng., 128, 186-195, https://doi.org/10.1061/(ASCE)07339372(2002)128:2(186), 2002.

Škrdlíková, L., Landlová, L., Klánová, J., and Lammel, G.: Wet deposition and scavenging efficiency of gaseous and particulate phase polycyclic aromatic compounds at a central European suburban site, Atmos. Environ., 45, 4305-4312, https://doi.org/10.1016/j.atmosenv.2011.04.072, 2011.

Statistics Norway: Registered vehicles, by region, statistical variable per year, data for 2018, available at: https://www.ssb.no/ statbank/table/11823/ (last access: 5 June 2020), 2018.

Tobiszewski, M. and Namieśnik, J.: PAH diagnostic ratios for the identification of pollution emission sources, Environ. Pollut., 162, 110-119, https://doi.org/10.1016/j.envpol.2011.10.025, 2012.

Tomaz, S., Shahpoury, P., Jaffrezo, J.-L., Lammel, G., Perraudin, E., Villenave, E., and Albinet, A.: One-year study of polycyclic aromatic compounds at an urban site in Grenoble (France): Seasonal variations, gas/particle partitioning and cancer risk estimation, Sci. Total Environ., 565, 1071-1083, https://doi.org/10.1016/j.scitotenv.2016.05.137, 2016.

UK Air DEFRA: The air quality strategy for England, Scotland, Wales and Northern Ireland, Department for Environment, Food and Rural Affairs, UK Air, 1, 56 pp., available at: https://assets.publishing.service.gov.uk/ government/uploads/system/uploads/attachment_data/file/ 69336/pb12654-air-quality-strategy-vol1-070712.pdf

(last access: 5 June 2020), 2007.
UNECE: The 1998 Aarhus protocol on persistent organic pollutants (POPs), 49 pp., availble at: https://www.unece.org/env/ 1rtap/pops_h1.html (last access: 5 June 2020), 1998.

US EPA: Polycyclic Aromatic Hydrocarbons on the Gulf Coastline: available at: https://archive.epa. gov/emergency/bpspill/web/html/pahs.html\#: :text=

PolycyclicAromaticHydrocarbons(PAHs)are,commonlycalled' weatheredoil' (last access: 5 June 2020), 2011.

Volvo trucks: Volvo D13 Engine family: available at: https: //www.volvotrucks.us/-/media/vtna/files/shared/powertrain/ revised4147_101-volvo_d13_engine-brochure_low-res.pdf, last access: 5 June 2020.

Wang, G., Ma, Z., Deng, J., Li, Z., Duan, L., Zhang, Q., Hao, J., and Jiang, J.: Characteristics of particulate matter from four coal-fired power plants with low-low temperature electrostatic precipitator in China, Sci. Total Environ., 662, 455-461, https://doi.org/10.1016/j.scitotenv.2019.01.080, 2019.

Wang, K., Shen, Y., Zhang, S., Ye, Y., Shen, Q., Hu, J., and Wang, $\mathrm{X}$.: Application of spatial analysis and multivariate analysis techniques in distribution and source study of polycyclic aromatic hydrocarbons in the topsoil of Beijing, China, Environ. Geol., 56, 1041-1050, https://doi.org/10.1007/s00254-008-1204-5, 2009.

Wang, R., Liu, G., and Zhang, J.: Variations of emission characterization of PAHs emitted from different utility boilers of coal-fired power plants and risk assessment related to atmospheric PAHs, Sci. Total Environ., 538, 180-190, https://doi.org/10.1016/j.scitotenv.2015.08.043, 2015.

Weinbruch, S., Benker, N., Kandler, K., Schutze, K., Kling, K., Berlinger, B., Thomassen, Y., Drotikova, T., and Kallenborn, R.: Source identification of individual soot agglomerates in Arctic air by transmission electron microscopy, Atmos. Environ., 172, 47-54, https://doi.org/10.1016/j.atmosenv.2017.10.033, 2018.

WHO: Environmental health criteria 229. Selected nitro- and nitrooxy-polycyclic aromatic hydrocarbons, World Health Organization, 2003.

Willis, M. D., Leaitch, W. R., and Abbatt, J. P. D.: Processes controlling the composition and abundance of Arctic aerosol, Rev. Geophys., 56, 621-671, https://doi.org/10.1029/2018rg000602, 2018.

Wingfors, H.: Characterisation and determination of profiles of polycyclic aromatic hydrocarbons in a traffic tunnel in Gothenburg, Sweden, 35, 6361-6369, https://doi.org/10.1016/s13522310(01)00389-2, 2001.

Wu, D., Wang, Z., Chen, J., Kong, S., Fu, X., Deng, H., Shao, G., and Wu, G.: Polycyclic aromatic hydrocarbons (PAHs) in atmospheric $\mathrm{PM}_{2.5}$ and $\mathrm{PM}_{10}$ at a coal-based industrial city: Implication for $\mathrm{PAH}$ control at industrial agglomeration regions, China, Atmos. Res., 149, 217-229, https://doi.org/10.1016/j.atmosres.2014.06.012, 2014.

Yang, H.-H., Lee, W.-J., Chen, S.-J., and Lai, S.-O.: PAH emission from various industrial stacks, J. Hazard. Mater., 60, 159-174, https://doi.org/10.1016/s0304-3894(98)00089-2, 1998.

Yu, Y., Katsoyiannis, A., Bohlin-Nizzetto, P., Brorström-Lundén, E., Ma, J., Zhao, Y., Wu, Z., Tych, W., Mindham, D., Sverko, E., Barresi, E., Dryfhout-Clark, H., Fellin, P., and Hung, H.: Polycyclic aromatic hydrocarbons not declining in Arctic air despite global emission reduction, Environ. Sci. Technol., 53, 23752382, https://doi.org/10.1021/acs.est.8b05353, 2019. 
Yunker, M. B., Macdonald, R. W., Vingarzan, R., Mitchell, R. H., Goyette, D., and Sylvestre, S.: PAHs in the Fraser river basin: a critical appraisal of PAH ratios as indicators of PAH source and composition, Org. Geochem., 33, 489-515, https://doi.org/10.1016/s0146-6380(02)00002-5, 2002.

Zhang, F., Chen, Y., Cui, M., Feng, Y., Yang, X., Chen, J., Zhang, Y., Gao, H., Tian, C., Matthias, V., and Liu, H.: Emission factors and environmental implication of organic pollutants in PM emitted from various vessels in China, Atmos. Environ., 200, 302-311, https://doi.org/10.1016/j.atmosenv.2018.12.006, 2019.

Zhao, J., Zhang, Y., Wang, T., Sun, L., Yang, Z., Lin, Y., Chen, Y., and Mao, H.: Characterization of $\mathrm{PM}_{2.5^{-}}$ bound polycyclic aromatic hydrocarbons and their derivatives (nitro-and oxy-PAHs) emissions from two ship engines under different operating conditions, Chemosphere, 225, 43-52, https://doi.org/10.1016/j.chemosphere.2019.03.022, 2019.

Zhao, J., Zhang, Y., Chang, J., Peng, S., Hong, N., Hu, J., Lv, J., Wang, T., and Mao, H.: Emission characteristics and temporal variation of PAHs and their derivatives from an ocean-going cargo vessel, Chemosphere, 249, 126194, https://doi.org/10.1016/j.chemosphere.2020.126194, 2020.
Zhao, S., Duan, Y., Yao, T., Liu, M., Lu, J., Tan, H., Wang, X., and $\mathrm{Wu}, \mathrm{L}$. : Study on the mercury emission and transformation in an ultra-low emission coal-fired power plant, Fuel, 199, 653-661, https://doi.org/10.1016/j.fuel.2017.03.038, 2017.

Zhao, T., Yang, L., Huang, Q., Zhang, W., Duan, S., Gao, H., and Wang, W.: $\mathrm{PM}_{2.5}$-bound polycyclic aromatic hydrocarbons (PAHs) and nitrated-PAHs (NPAHs) emitted by gasoline vehicles: Characterization and health risk assessment, Sci. Total Environ., 727, 138631, https://doi.org/10.1016/j.scitotenv.2020.138631, 2020.

Zheng, L., Ou, J., Liu, M., Chen, Y., Tang, Q., and Hu, Y.: Seasonal and spatial variations of $\mathrm{PM}_{10}$-bounded PAHs in a coal mining city, China: Distributions, sources, and health risks, Ecotox. Environ. Safe., 169, 470-478, https://doi.org/10.1016/j.ecoenv.2018.11.063, 2019. 